\title{
Synthesis Paper Ecology and management of sage-grouse and sage-grouse habitat
}

\author{
JOHN A. CRAWFORD, RICH A. OLSON, NEIL E. WEST, JEFFREY C. MOSLEY, MICHAEL A. SCHROEDER, \\ TOM D. WHITSON, RICHARD F. MILLER, MICHAEL A. GREGG, AND CHAD S. BOYD
}

Authors are Professor, Department of Fisheries and Wildlife, Oregon State University, Nash Hall 104 Corvallis, Ore., 97331-3803; Professor, Department of Renewable Resources, University of Wyoming, Box 3354, Laramie, Wyo. 82701-3354; Professor, Department of Forest, Range, and Wildlife Sciences, Utah State University, Logan, Utah, 84322-5230; Professor, Department of Animal and Range Sciences, Montana State University, Bozeman, Mont. 597I7-2820; Research Biologist, Washington Department of Fish and Wildlife, Bridgeport, Wash. 98813; Professor, Department of Plant Sciences, University of Wyoming, 747 Road 9, Powell, Wyo. 82435-9135; Professor, Department of Rangeland Resources, Oregon State University, Eastern Oregon Agricultural Research Center, 67826-A Hwy 205, Burns, Ore. 97720; Biologist, US Fish and Wildlife Service. Sheldon-Hart Mountain Refuges, P.O. Box 111, 18 South G Street. Lakeview, Ore. 97630; Rangeland Scientist, U.S.D.A.-ARS, Eastern Oregon Agricultural Research Center, 67826-A Hwy 205, Burns, Ore. 97720.

\section{Abstract}

Sage-grouse (Centrocercus urophasianus and $C$. minimus) historically inhabited much of the sagebrush-dominated habitat of North America. Today, sage-grouse populations are declining throughout most of their range. Population dynamics of sagegrouse are marked by strong cyclic behavior. Adult survival is high, but is offset by low juvenile survival, resulting in low productivity. Habitat for sage-grouse varies strongly by life-history stage. Critical habitat components include adequate canopy cover of tall grasses ( $\geq 18 \mathrm{~cm}$ ) and medium height shrubs (40-80 $\mathrm{cm}$ ) for nesting, abundant forbs and insects for brood rearing, and availability of herbaceous riparian species for late-growing season foraging. Fire ecology of sage-grouse habitat changed dramatically with European settlement. In high elevation sagebrush habitat, fire return intervals have increased (from 12-24 to $>50$ years) resulting in invasion of conifers and a consequent loss of understory herbaceous and shrub canopy cover. In lower elevation sagebrush habitat, fire return intervals have decreased dramatically (from 50-100 to $<10$ years) due to invasion by annual grasses, causing loss of perennial bunchgrasses and shrubs. Livestock grazing can have negative or positive impacts on sagegrouse habitat depending on the timing and intensity of grazing, and which habitat element is being considered. Early season light to moderate grazing can promote forb abundance/availability in both upland and riparian habitats. Heavier levels of utilization decrease herbaceous cover, and may promote invasion by undesirable species. At rates intended to produce high sagebrush kill, herbicide-based control of big sagebrush may result in decreased habitat quality for sage-grouse. Light applications of tebuthiuron (N-[5-(1,1-dimethylethyl)-1,3,4-thiadiazol-2-yl]-N,N'-dimethylurea) can decrease canopy cover of sagebrush and increase grass and forb production which may be locally important to nesting

This project was initiated by the Society for Range Management Wildlife Habitat Committee. Larry Rittenhouse provided comments and suggestions for the initial outline and Tim Westfall provided suggestions on content, helped assemble the team of authors, and provided insightful comments on portions of an earlier draft of the manuscript.

Authors are listed in order of random draw.

Corresponding author is Chad S. Boyd.

Manuscript accepted 20 Sept. 03.

\section{Resumen}

EI "Sage-grouse" (Centrocercus urophasianus and C. minimus) históricamente habitó gran parte del hábitat dominado por "Sagebrush" de Norteamérica. Actualmente, las poblaciones de "Sage-grouse" están disminuyendo a través de la mayor parte de su rango de adaptación. Las dinámicas de población del "Sagegrouse" están marcadas por un comportamiento fuertemente cíclico. La supervivencia de adultos es alta, pero es anulada por la baja supervivencia juvenil, resultando en una baja productividad. El hábitat del "Sage-grouse" varía fuertemente con la etapa de la historia de vida. Los componentes críticos de hábitat incluyen una adecuada cobertura de copa de zactaes altos ( $>18$ cm) y arbustos medianos $(40-80 \mathrm{~cm})$ para anidar, abundantes hierbas e insectos para criar la camada y disponibilidad de hierbas ribereñas para el forrajea a finales de la estación de crecimiento. La ecología del fuego del hábitat del "Sage-grouse" cambio dramáticamente con la con la colonización europea. EI las altas elevaciones del hábitat de "Sagebrush", los intervalos de retorno del fuego ha incrementado (de 12 - 24 a >50 años) resultando en una invasión de coníferas y una consecuente perdida del estrato herbáceo y de la cobertura de arbustos. En las bajas elevaciones del hábitat de "Sagebrush" los intervalos de retorno del fuego han disminuido (de $50-100$ a $<10$ años) debido a la invasión de zacates anuales, causando una perdida de zacates perennes amacollados y arbustos. El apacentamiento del ganado puede tener impactos positivos o negativos en el hábitat del "Sage-grouse"dependiendo de la época e intensidad del apacentamiento y cual elemento del hábitat esta siendo considerado. A inicios de la estación el apacentamiento ligero a moderado puede promover la abundancia/disponibilidad de hierbas tanto en los hábitats de tierras altas como en los ribereños. Niveles fuertes de utilización disminuyen la cobertura de herbáceas y puede promover la invasión de especies indeseables. A las tasas con las que se intenta producir una alta muerte de "Sagebrush", el control del "Big sagebrush" basado en herbicidas puede resultar en una disminución de la calidad del hábitat para el "Sage-grouse". Aplicaciones ligeras de tebuthiuron (N-[5-(1,1-dimetiletil)-1,3,4tiadiazol-2-yl]-N,N'-dimetilurea) puede disminuir la cobertura de "Sagebrush" $\mathrm{e}$ incrementar la producción de zacates y hierbas lo cual puede ser localmente importantes para las actividades de anidamiento y forrajeo. La capacidad de los mane- 
and foraging activities. The ability of resource managers to address sage-grouse habitat concerns at large scales is aided greatly by geomatics technology and advances in landscape ecology. These tools allow unprecedented linkage of habitat and population dynamics data over space and time and can be used to retroactively assess such relationships using archived imagery. The present sage-grouse decline is a complex issue that is likely associated with multiple causative factors. Solving management issues associated with the decline will require unprecedented cooperation among wildlife biology, range science, and other professional disciplines.

escala del hábitat del "Sage-grouse" es auxiliada grandemente por la tecnología geomática y los avances en la ecología de paisaje. Estas herramientas permiten un enlace sin precedentes entre los datos del hábitat y las dinámicas de la población a través del espacio y tiempo y pueden ser usadas retroactivamente para evaluar tales relaciones utilizando las imágenes archivadas. La disminución presente del "Sage-grouse" es un problema complejo que probablemente esta asociado con múltiples factores causales. La resolución de los problemas de manejo asociados con la diminución requerirá una cooperación sin precedentes entre las ciencias de biología de fauna silvestre, manejo de pastizales y otras disciplinas profesionales.

Key Words: population dynamics, habitat, fire ecology, livestock grazing, herbicide, landscape ecology

Historically, greater (Centrocercus urophasianus) and Gunnison (C. minimus) sage-grouse inhabited large portions of sagebrush-dominated North American rangelands [both sagebrush steppe and sagebrush semi-desert plant assemblages (West 1983a, 1983b, West and Young 2000)]. The subfamily Tetraoninae is reported to be of North American origin (Lucchini et al. 2001), and at one time, the range of sage-grouse encompassed significant portions of the western (US) states and extended north into the Canadian provinces of British Columbia, Alberta, and Saskatchewan (Fig. 1). Many plant communities providing habitat to sagegrouse have undergone significant, and in some cases, lasting changes in the $1.9^{\text {th }}$ and $20^{\text {th }}$ centuries. Factors responsible for plant community change have included (but are not limited to) alterations in fire regime; excessive livestock grazing; pro-

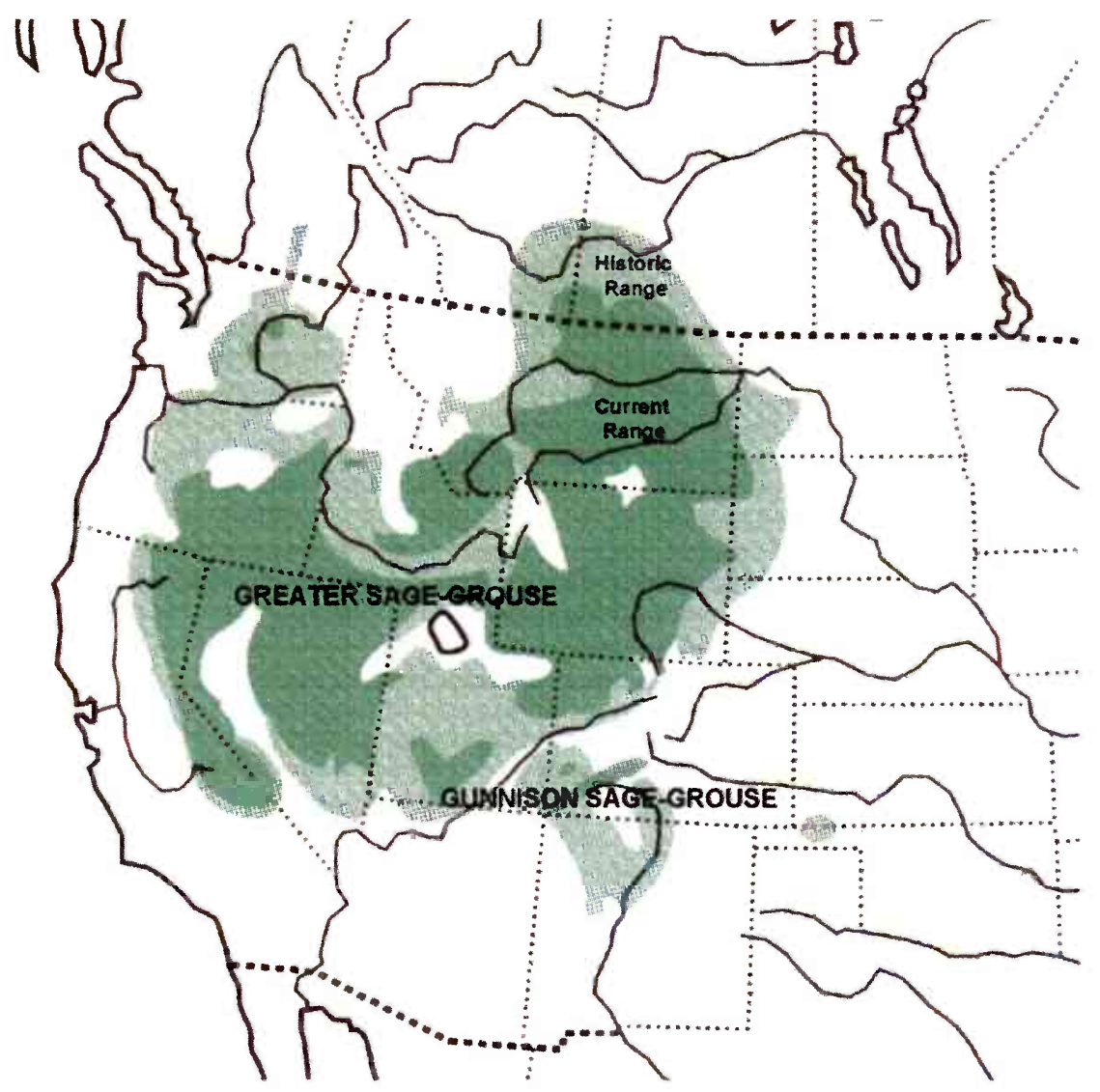

Fig. 1. Historical (light shading) and current (dark shading) range of greater (Centrocercus urophasianus) and Gunnison (C. minimus) sage-grouse. Gunnison sage grouse historically occurred in Oklahoma, Colorado, and Kansas, and are currently found south of Eagle River in Colorado. Adapted from Shroeder et al. (1999) and courtesy of A. Poole and F. Gill (eds.) The Birds of North America. 1999.

liferation of non-native plant species; conversion of rangeland to seeded pastures [e.g. crested wheatgrass (Agropyron cristatum L.)], cropland and roads; and other land alterations. Concurrent with these habitat changes has been a generalized decline in sage-grouse abundance. The reasons for this decline are difficult to understand. Putting together the pieces of the puzzle involves integrating sagegrouse population ecology and habitat requirements, as well as the ecology and management of plant communities that comprise sage-grouse habitat. It is critical that the relationship between changes in habitat, and changes in sage-grouse populations be defined at multiple scales, given the extended temporal and spatial horizons that frame the ecology of these species.

This paper synthesizes current knowledge regarding pertinent topics in sagegrouse ecology and management and suggests direction for future research and management. Others (Braun et al. 1977, Beck and Mitchell 2000, Connelly et al.
2000, Rowland and Wisdom 2002) have provided synthesis and review papers previously. Our effort is not comprehensive to all factors affecting sage-grouse, but is meant to provide expanded coverage of topical management concerns with an emphasis on habitat ecology.

\section{Population ecology}

Connelly and Braun (1997) estimate a $17-47 \%$ decline in sage-grouse breeding populations since 1985 in states that have sufficient records for quantifying sagegrouse numbers. For many years periodic fluctuations in abundance were attributed to cycles, often over 8-12 year intervals (Batterson and Morse 1948, Rich 1985). Nevertheless, an explanation for fluctuations in abundance has been difficult to support with documented causal relationships (Braun 1998). Although the mechanisms underlying fluctuations in abundance 
Table 1. Range-wide averages for demographic parameters associated with population dynamics of greater (Centrocercus urophasianus) and Gunnison (C.minimus) sage-grouse in North America (Rasmussen and Griner 1938, Bean 1941, Keller et al. 1941, Batterson and Morse 1948, Patterson 1952, Nelson 1955, June 1963, Wallestad and Pyrah 1974, Wallestad 1975, Petersen 1980, Wakkinen 1990, Connelly et al. 1993, 1994, Zablan 1993, Gregg et al. 1994, Hanf et al. 1994, Young 1994, Schroeder 1997, Sveum et al. 1998a, 1998b, Schroeder et al. 1999, Aldridge 2000).

\begin{tabular}{|c|c|c|c|c|}
\hline \multirow[b]{2}{*}{ Parameter } & \multicolumn{2}{|c|}{$\begin{array}{c}\text { Greater } \\
\text { sage-grouse }\end{array}$} & \multicolumn{2}{|c|}{$\begin{array}{l}\text { Gunnison } \\
\text { sage-grouse }\end{array}$} \\
\hline & $\overline{\mathbf{x}}$ & $\mathbf{n}$ & $\bar{x}$ & $\mathbf{n}$ \\
\hline Clutch size & 7.5 eggs & 10 studies & 6.8 eggs & l study \\
\hline Hatchability & $94.3 \%$ & 8 studies & & \\
\hline Nest likelihood $^{\mathrm{a}}$ & $80.8 \%$ & 7 studies & $75.7 \%$ & l study \\
\hline Renest likelihood $^{\mathrm{b}}$ & $32.5 \%$ & 7 studies & $4.8 \%$ & 1 study \\
\hline Nest success ${ }^{c}$ & $47.4 \%$ & 14 studies & $43.2 \%$ & I study \\
\hline Annual reproductive success ${ }^{d}$ & $44.6 \%$ & 8 studies & $35.1 \%$ & I study \\
\hline $\begin{array}{l}\text { Annual survival of } \\
\text { breeding-aged males }\end{array}$ & $48.9 \%$ & 5 studies & & \\
\hline $\begin{array}{l}\text { Annual survival of } \\
\text { breeding-aged females }\end{array}$ & $60.6 \%$ & 6 studies & & \\
\hline Survival of juveniles ${ }^{e}$ & $10.0 \%$ & 3 studies & & \\
\hline
\end{tabular}

The proportion of females attempting to nest.

The propotion of females attempting to renest following their first nest failure.

c The probability of a single nest hatching $\geq 1 \mathrm{egg}$.

dTe probability of a female hatching $\geq 1 \mathrm{egg}$ in a season.

Approximate estimate of survival to the first potential breeding season based on partial estimates from 3 studies.

are still debated, the major concern now is that most (but not all) populations are showing long-term declines, whether cyclic in the short-term or not (Braun 1998).

\section{Productivity, survival and recruitment}

The dynamics of a population are a reflection of productivity, survival, and recruitment. Productivity can be further divided into stages, including clutch size, hatchability, nest likelihood, renest likelihood, nest success, and annual reproductive success (Schroeder et al. 1999; Table 1). Sage-grouse productivity is low, despite their high reproductive potential. Declines in productivity appear to be related to a substantial number of non-nesting females (nest/renest likelihood in Table 1) and low rate of annual reproductive success. Nest success is inversely correlated with density of predators, such as common ravens (Corvus corax, Batterson and Morse 1948), however, rates of predation are tied to habitat quality, and it has been suggested that the most efficient method for mitigating high rates of nest predation may be through the effective management of habitat (Hamerstrom et al. 1957, Angelstam 1986, Andrén and Angelstam 1988, Schroeder and Baydack 2001). The impact of re-nesting on productivity is unclear; renesting has had limited impact on overall productivity in Oregon (Gregg et al. 1994, Hanf et al. 1994) and Idaho (Connelly et al. 1993), however, Schroeder (1997) reported that $38 \%$ of productivity in north-central Washington was due to re-nesting.
Productivity, and subsequently recruitment, is further impacted by low juvenile survival rates between hatch and the following breeding season (Table 1). Juvenile survival has proven difficult to document in the field but the available estimates for this parameter are very low, suggesting that understanding juvenile survival may be critical in managing the population dynamics of sage-grouse. Food availability (Pyle and Crawford 1996), habitat quality (Sveum et al. 1998a), harvest (Crawford and Lutz 1985), predation (Batterson and Morse 1948), and weather (Blake 1970, Rich 1985) all affect juvenile survival. Recruitment of young birds into the breeding population may be further complicated by dispersal of juveniles from the nesting location (Browers and Flake 1985, Dunn and Braun 1985, 1986). The direct impact of dispersal on population dynamics of sage-grouse remains largely unexplored.

In contrast to low nest success and low survival of juveniles, annual survival of breeding-aged birds tends to be higher than $50 \%$ in most situations, and as high as $75 \%$ for breeding-aged females in Idaho (Connelly et al. 1994). Although high adult survival rates may compensate for low productivity, it has been insufficient to reverse their widespread declines in abundance (Braun 1998).

\section{Population fluctuations and \\ research needs}

The relatively high survival rates and low productivity of adult sage-grouse may help explain the dramatic fluctuations in sage-grouse abundance that some have suggested resemble "cycles" (Rich 1985). Although sage-grouse have a high reproductive potential, they may only rarely have years where productivity is high. These infrequent "boom" years, in combination with the high survival of breedingaged birds, may produce multi-year fluctuations in abundance.

Dramatic fluctuations in abundance (Rich 1985) create tremendous problems for evaluating population-level responses to management. For example, although habitat quality is related to sage-grouse population dynamics (Edelmann et al. 1998), there are 4 basic reasons why most management changes require years before a population change is detected. First, changes in habitat management do not immediately alter habitat characteristics. This is particularly true where habitat has undergone gradual, long-term structural and/or compositional changes. Second, sage-grouse population response may lag behind changes in sage-grouse productivity. This lag effect occurs because yearling males may not display on leks (Jenni and Hartzler 1978, Emmons and Braun 1984) and yearling females may not nest (Connelly et al. 1993, Gregg et al. 1994) during their first potential breeding season. Third, population responses to shortterm habitat management $(<10$ years) may not be observed in sage-grouse populations, because the typical fluctuations in a 10-year interval may dwarf any response to improved management. Fourth, the lack of basic information on important stages in the life history of sage-grouse, such as juvenile survival, may indicate that the appropriate habitat management strategy for a given population is not yet known.

Habitat management is one of the few areas where research has shown that reproductive parameters can be altered. For example, substantial data exists documenting significant relationships between specific habitat characteristics and annual reproductive success (Bean 1941, Pyrah 1971, Wallestad and Pyrah 1974, Connelly et al. 1991, Gregg et al. 1994, Hanf et al. 1994, Young 1994, DeLong et al. 1995, Sveum et al. 1998b). Adequate habitat provides the cover necessary to conceal nests and provides the foods necessary for hens to lay eggs and incubate clutches (Barnett and Crawford 1994). Manipulation of habitat also has potential to influence other aspects of sage-grouse population dynamics including clutch size, nest and renest likelihood, and survival of juveniles and breeding-aged birds. For example, adequate vegetational canopy cover may pro- 
vide critical escape cover, thus lowering the risk of predation.

Although many of the specific relationships between habitat quality and productivity and survival are not clear, the overall relationship can be illustrated by the dramatic changes in landscape throughout the historical North American range of sage-grouse. Most remaining populations are associated with intact habitats in relatively northern latitudes, high elevations, and/or mesic environments (Connelly and Braun 1997). In contrast, significantly altered habitats and those in southern latitudes, low elevations, and/or xeric environments have become uninhabitable. This is a trend that has been ongoing for the past 100 years and is likely to continue unless there are widespread changes in management (Brown and Davis 1995). In addition, the continued reduction in occupied habitat will result in increased fragmentation and isolation of remaining sagegrouse populations.

Although a substantial quantity of data exists on some basic parameters associated with population dynamics (e.g., clutch size, egg hatchability, nesting success, survival of breeding age birds), information on juvenile survival, dispersal, and recruitment is inadequate. It is essential that research be initiated as soon as possible, because of the dramatic declines in sagegrouse distribution and abundance (Connelly and Braun 1997, Braun 1998) and because of the long time periods ( $>10$ years) needed to observe treatment effects in a species with low productivity and high survival. It is also critical that other research continues, including the influence of nutrition (Barnett and Crawford 1994, Pyle and Crawford 1996), weather (Gill 1966, Blake 1970, Hupp and Braun 1989), predation (Batterson and Morse 1948, Schroeder and Baydack 2001), and behavior (Scott 1942, Gibson and Bradbury 1986) on population dynamics.

\section{Sage-grouse habitat relationships}

While many factors likely influence productivity, the only factor that has been consistently manageable is habitat (Connelly et al. 1991, Gregg et al. 1994, DeLong et al. 1995, Sveum et al. 1998b). The importance of sagebrush (woody Artemisia) as a source of cover and food for sage-grouse is well known (Patterson 1952, Braun et al. 1977), however, sagegrouse require a variety of plant community types for breeding, nesting, brood-rearing and wintering (Table 2). Describing habitat relationships is complicated by the fact that sage-grouse populations often display complex seasonal movement patterns. Populations may exhibit different patterns of migration, with some populations remaining resident throughout the year, some migrating between wintering and breeding habitat, and some with more complicated movements (Connelly et al.
1988). Migratory birds in Idaho have been reported to range up to $125 \mathrm{~km}$, with an annual home range size of $2,764 \mathrm{~km}^{2}$ (Leonard et al. 2000). For management purposes, spatial patterns of habitat use over time should be determined on a population-by-population basis.

\section{Winter habitat}

During winter, sage-grouse utilize medium to tall sagebrush communities (25-80 $\mathrm{cm}$, or 25-35 $\mathrm{cm}$ above the snow) on south and west facing slopes (Ihli et al. 1973, Connelly et al. 2000; Table 2), and forage primarily on sagebrush leaves (Patterson 1952). Where available, low sagebrush (A. arbuscula Nutt.) habitat (particularly on wind-swept ridges) is also used (Hanf et al. 1994). Home range for wintering migratory and non-migratory populations has been reported as $>140 \mathrm{~km}^{2}$ (Robertson 1991) and 11 to $31 \mathrm{~km}^{2}$ (Wallestad 1975), respectively. Sagebrush canopy cover at sage-grouse winter use sites can range from $12 \%$ in Oregon (Hanf et al. 1994) to $43 \%$ in Colorado (Schoenberg 1982), but adequate cover is typically available on a landscape scale (Connelly et al. 2000). Unless snow completely covers sagebrush (Hupp and Braun 1989), severe winter weather conditions have little effect on sage-grouse populations (Call and Maser 1985) and sagegrouse may actually gain weight during the winter months (Beck and Braun 1978).

Table 2. Sage grouse habitat/reproductive parameters and key plant community and dietary/structural components (Ihli et al. 1973, Hulet et al. 1986, Gregg et al. 1993, 1994, Barnett and Crawford 1994, Drut et al. 1994a, 1994b, Delong et al. 1995, Sveum et al. 1998a, 1998b, Schroeder et al. 1999, Connelly et al. 2000, Aldridge and Brigham 2002).

\begin{tabular}{lll}
\hline \hline Habitat/reproductive parameter & Plant community type & Important dietary/structural components \\
\hline Winter & Big sagebrush (Artemisia tridentata ssp. & Medium height (25-80 cm) and taller \\
& $\begin{array}{l}\text { wyomingensis } \text { Welsh and ssp. vaseyana Rydb.) } \\
\text { but other species may be used (e.g. A. arbuscula } \text { Nutt., }\end{array}$ & sagebrush on south and west exposures, \\
& windswept low sagebrush
\end{tabular}

Lekking

Pre-laying:

Nest and renest initiation

Nesting:

Nest and renest success

Brood-rearing:

Chick survival and recruitment
Sparsely vegetated areas on ridgetops, swales, and dry lakebeds (burned areas, grassy meadows, plowed fields, or cleared roadsides may also be used)

Low sagebrush (A. arbuscula, A nova A. Nels., $A$. rigida Nutt.) and Wyoming big sagebrush (A.t. ssp. wyomingensis)

Sagebrush (A. arbuscula, A. cana, A. tridentata. ssp. wyomingensis and vaseyana, A. tripartita $\mathrm{Rydb}$.), bitterbrush (Purshia tridentata Pursh DC.) and rabbitbrush (Chrysothamnus spp. Nutt.)

Big and low sagebrush, riparian habitat

Broodless hens and males (growing season)
Big and low sagebrush, riparian habitat
Low or absent vegetation canopy ( 0.04 ha to 4 ha in size) within sagebrush sites

Key forbs (legumes and composites) and sagebrush

Tall $(>18 \mathrm{~cm})$ residual bunchgrass cover, medium height shrubs $(40-80 \mathrm{~cm})$

Key forbs (legumes and composites) and insects, succulent mesic vegetation and sagebrush 


\section{Lekking habitat}

Leks are typically located in sparsely vegetated areas (Call and Maser 1985) with few to 100 or more displaying males. Leks typically reflect the availability of nesting habitat in the surrounding area. There is no evidence that lek habitat is limiting to sage-grouse populations (Schroeder et al. 1999), and, if needed, lekking habitat can be created by management activity (Eng et al. 1979, Tate et al. 1979).

\section{Pre-laying habitat}

The pre-laying period is defined as the 5 -week period preceding incubation (Barnett 1992) when habitat use centers around low sagebrush (A. arbuscula Nutt., but also, $A$. nova A. Nels. and $A$. rigida Nutt.) and Wyoming big sagebrush (A. tridentata ssp. wyomingensis $\mathrm{Rydb}$.) communities (Table 2). During this period 50$80 \%$ of the hen's diet is sagebrush with the remainder being mostly forbs (Barnett and Crawford 1994). Although sagebrush leaves contribute importantly to the dry mass of the diet of pre-laying hens, the nutrient contribution of forbs overshadows that of sagebrush and may be associated with increased reproductive success (Barnett and Crawford 1994). Some authors (e.g., Rogers 1964, Patterson 1952, Wallestad et al. 1975) have reported that sagebrush comprises $>85 \%$ of the diet during the pre-laying period. However, these authors did not separate diets by sex.

\section{Nesting habitat}

Sage-grouse nests are typically located under sagebrush plants, often in mountain big sagebrush (A. $t$. ssp. vaseyana $\mathrm{Rydb}$ ) habitat (Wallestad and Pyrah 1974, Gregg et al. 1994). A variety of other sagebrushdominated community types as well as bitterbrush (Purshia tridentata Pursh DC.) and rabbitbrush (Chrysothamnus spp. Nutt.) sites may also be utilized (Hulet et al. 1986, Crawford et al. 1992, Aldridge and Brigham 2002; Table 2). Nests are generally located near leks, but hens may move long distances from leks to nest (Hanf et al. 1994). In Idaho, 55\% of nests were within $3 \mathrm{~km}$ of the lek of capture (Wakkinen et al. 1992). Poor reproductive success may result from a lack of key structural habitat features necessary for nesting (Blake 1970, Autenrieth 1981). Nest site selection is largely a function of height and amount of shrub canopy cover (Klebenow 1969, Roberson 1986, Gregg $1992)$, while tall $(>18 \mathrm{~cm})$ residual bunchgrasses provide cover for screening (Gregg 1992, Gregg et al. 1994).
Successful nests in Oregon had $41 \%$ canopy cover of medium height (40-80 $\mathrm{cm}$ ) sagebrush and $18 \%$ tall bunchgrass (residual) canopy cover in the $3-\mathrm{m}^{2}$ area surrounding the nest (Gregg et al. 1994). Other forms of herbaceous vegetation (e.g., residual forbs) may provide nest screening cover (Sveum et al. 1998b), however, exotic invaders (e.g., cheatgrass Bromus tectorum L.) generally do not. Sagebrush canopy cover in nesting habitat should range from 15-25\% (Connelly et al. 2000). Winward (1991) suggested that maximum understory herbaceous production would be realized at $12 \%$ sagebrush cover in Wyoming big sagebrush types and $20 \%$ sagebrush cover in mountain big sagebrush types.

The most common reason for nest failure is predation by coyotes (Canis latrans) and avian and small mammal species (Batterson and Morse 1948, Nelson 1955, Autenrieth 1981, DeLong 1994). However, adequate vegetation structure at the nest site provides visual, scent and physical barriers between ground nesting birds and predators, and may ultimately determine susceptibility to predation (Gregg 1992, Gregg et al. 1994). Canopy cover of tall grasses and medium height sagebrush is inversely related to the probability of nest predation in big sagebrush habitats (Connelly et al. 1991, Delong et al. 1995, Sveum et al. 1998b).

\section{Brood-rearing habitat}

The pattern of habitat use during the brood-rearing period is related to changes in food availability and hens with broods are typically found where forb abundance is greatest (Klebenow 1969, Drut et al. 1994a). For example, Sveum et al. (1998a) reported $>20 \%$ canopy cover of forbs at brood-rearing sites and decreased shrub canopy cover ( 14 vs. $20 \%$ ) relative to random locations in Wyoming big sagebrush habitat. Specific habitats used during brood-rearing (Table 2) are more mesic as the growing season progresses, which is associated with forb desiccation (Wallestad 1971). Home range size for broods has been reported to range from less than 1 $\mathrm{km}^{2}$ in Montana (Wallestad 1971) to $5 \mathrm{~km}^{2}$ in Oregon (Drut et al. 1994a). Differences in home range size among broods have been attributed to availability of forbs (Drut et al. 1994a). Use of riparian habitat is dependent on desiccation of forbs in sagebrush uplands and may occur earlier in drought years (Savage 1969, Oakleaf 1971, Danvir 2002).

Forbs and insects comprise the bulk of sage-grouse chick diets until they are approximately 12 weeks of age, at which time sagebrush becomes a common component (Dargen et al. 1942, Nelson 1955, Klebenow and Gray 1968, Peterson 1970). Specific taxa consumed by chicks are very diverse. In Oregon chicks consumed 41 families of invertebrates, 34 genera of forbs, 2 genera of shrubs, and 1 genus of grass (Pyle 1993, Drut et al. 1994b), however, only a few specific taxa of forbs were preferentially selected (Drut et al. 1994b). The relationship between chick survival/recruitment and dietary factors has not been elucidated for most wild galliformes, especially the tetraonids (Potts 1986). However, data suggest that availability of forbs and invertebrates is associated positively with survival/recruitment of sage-grouse chicks (Drutt et al. 1994b). This relationship may be of particular importance during drought years when forb availability is low and sagebrush becomes a greater component of the chick diet at an earlier age (Drut et al. 1994a).

\section{Broodless hens and male habitat (growing season)}

Because sage-grouse nesting and broodrearing success is extremely low in some years, a relatively large portion of the summer female sage-grouse population is composed of broodless hens (Gregg et al. 1993). Survival of these hens may be important to population maintenance. Broodless hens begin to form small flocks of 2-3 birds in mid-May which may increase in size to 25 hens by early June (Gregg et al. 1993). Habitat use is similar to that of hens with broods (Table 2), however, broodless hens move to riparian habitat earlier than hens with broods (Dalke et al. 1963, Martin 1976, Gregg et al. 1993). Males follow a similar pattern of habitat use, but typically remain in flocks separate from females.

\section{Monitoring considerations and research needs}

Monitoring sage-grouse habitat is complicated by the migratory behavior of sage-grouse populations, or segments of populations (Connelly et al. 2000). As such, monitoring efforts and habitat assessments require knowledge of both the spatial and temporal dynamics of migratory patterns. However, these patterns do not directly influence the specific seasonal, community-scale habitat needs of sagegrouse populations. At present, establishing vegetation monitoring transects and quantifying availability of key habitat components (Connelly et al. 2000 and 
Table 2), coupled with an estimate of reproductive parameters, provides the best measure of sage-grouse habitat quality. Because all reproductive parameters may be important, evaluation of sage-grouse habitat must consider all of the key habitat components. A deficiency in any 1 factor can reduce productivity and ultimately abundance of sage-grouse in a particular area. Different critical habitat factors may limit sage-grouse populations in different areas.

There is a strong need to develop a consistent monitoring approach that focuses on the vegetation elements most important to sage-grouse at local (e.g., nest site), community, and landscape scales. Research is also needed to refine our knowledge of the optimal balance of key components (i.e., shrubs, grasses, and forbs) within seasonal habitats, and the optimal juxtaposition and interspersion of habitats across the landscape. Not much is known about the habitat factors that influence juvenile survival. Previous research has identified availability of key forbs as an important factor influencing juvenile survival. Other factors that may influence juvenile survival include physiological condition of the hen before nesting, insect availability, and the influence of vegetation structure and composition on predation. Understanding the relationship between habitat variables and juvenile survival is vital to understanding long-term fluctuations of sage-grouse populations.

\section{Impacts on sage-grouse habitat}

European settlement precipitated significant ecological changes in the sagebrush region (Miller and Eddleman 2001). For example, West (1999a) estimated that 4.5 million hectares of sagebrush steppe have been converted to towns, communication corridors, or intensive agriculture. In the nonarable regions, a large portion of sagebrush-dominated communities has been altered by changes in the proportion of trees, shrubs, grasses, and forbs. Changes in structure and composition in non-cultivated areas are primarily attributed to altered fire regimes, improperly managed livestock grazing, introduction of exotic plants, and herbicide use (Miller et al. 1994).

\section{Fire}

Management of both wild and prescribed fires is considered one of the key issues in maintaining sage-grouse populations in sagebrush-dominated landscapes. Sage-grouse evolved in ecosystems where fire was a primary disturbance process.

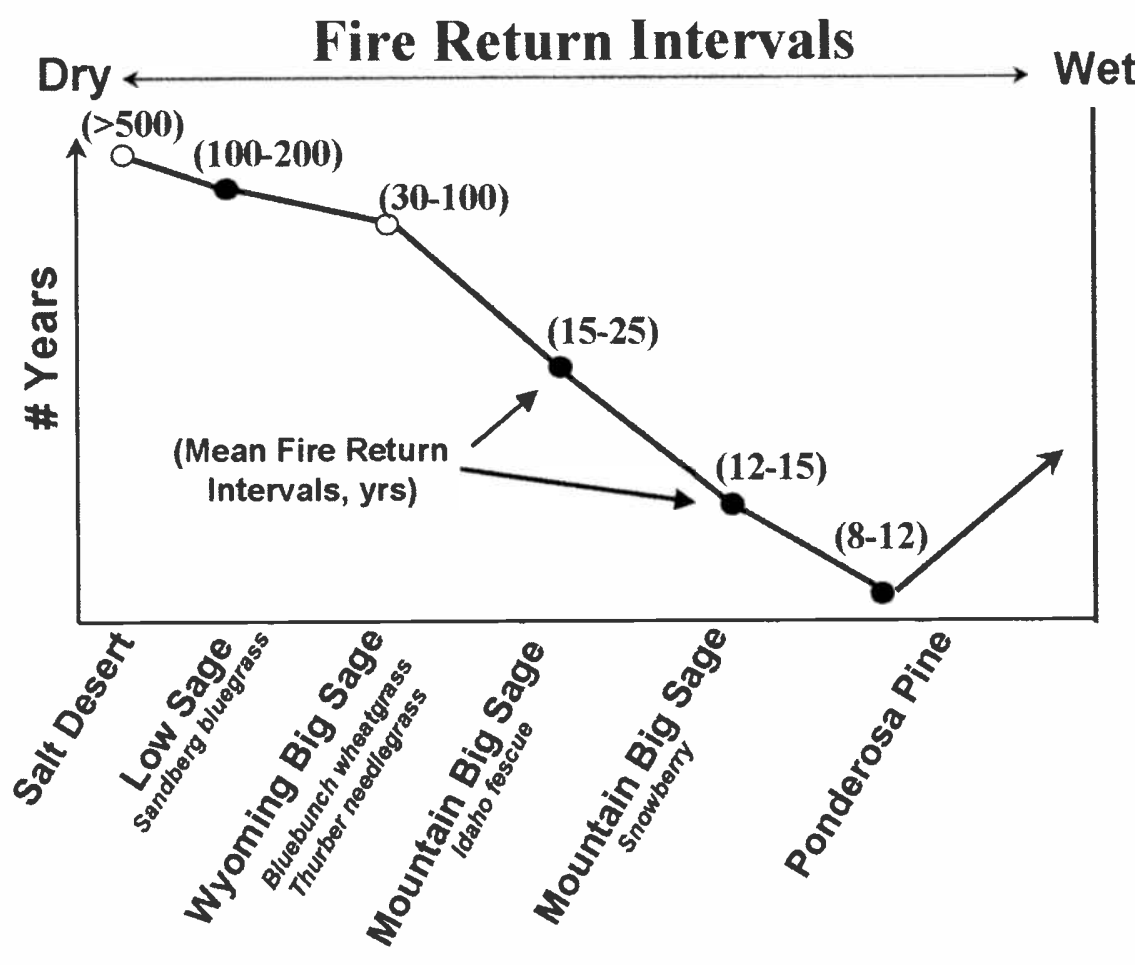

Fig. 2. Presettlement mean fire return intervals (MFRI) for salt desert, low sagebrush (Artemisia arbuscula Nutt.)/sandberg bluegrass (Poa sandbergii Vasey), Wyoming big sagebrush (A. tridentata ssp. wyomingensis Welsh.)/bluebunch wheatgrass (Agropyron spicatum Pursh)/Thurber needlegrass (Stipa thurberiana Piper), mountain big sagebrush (A.t. ssp. vaseyana Rydb.)/Idaho fescue (Festuca idahoensis Elmer), mountain big sagebrush/snowberry (Symphoricarpos spp.), and ponderosa pine (Pinus ponderosa Laws.) communities. Solid circles are MFRI estimates supported by data, and open circles are estimates with little to no information [from Riegel et al. (in press)].

However, the role of fire in the sagebrush biome is often over generalized. Fire regimes are spatially complex and vary through time across the sagebrush region, and, since the $1860 \mathrm{~s}$, the ecological role of fire has changed dramatically (West 1983b, 2000, West and Young 2000, Miller and Tausch 2001).

\section{Pre-European settlement}

Presettlement fire return interval varied greatly depending on plant community type and moisture regime (Fig. 2). For example, mean fire return interval (MFRI $=$ time between fires) varied between 12 and 25 years on productive mountain big sagebrush sites (Houston 1973, Burkhardt and Tisdale 1976, Gruell 1999, Miller and Rose 1999), but can exceed 200 years in more xeric mountain big sagebrush/western needlegrass (Stipa occidentalis Thurber) communities occupying sandy soils (Waichler et al. 2001, Miller unpublished data). Estimates of MFRI reported for Wyoming big sagebrush communities (Wright and Bailey 1982) are largely based on fuel loads and likely plant composition prior to settlement. However,
MFRI only partially describes the frequency of fire. The variability of fire-free periods within a fire regime is very important in determining landscape plant community composition, structure, and fire behavior. Information on the variability of presettlement fire-free periods is limited. Two studies conducted in mountain big sagebrush communities where MFRI was relatively short (10 to 20 years) reported that presettlement fire-free periods varied between 8-29 years (Gruell 1999), and 3-28 years (Miller and Rose 1999). Fire size and complexity (patchiness) are also important factors influencing seed source for plant re-establishment (particularly sagebrush) and wildlife use patterns.

The response of presettlement communities following fire was largely determined by the preburn plant composition and fire tolerances of those species. Many herbaceous species in sage-grouse habitat are well adapted to fire (Blaisdell 1953, Wright and Klemmedson 1965, Conrad and Poulton 1966, Wright and Bailey 1982, Young and Miller 1985). Forb species that resprout belowground from a caudex, corm, bulb, rhizome, or rootstock, 
Table 3. Generalized response of forbs common to the sagebrush region to fire and herbicide (2,4D) application (Blaisdell 1953, Pehanec et al. 1954, Payne 1973, Lyon and Stickney 1976, Klebenow and Beall 1977, Wright et al. 1979, Volland and Dell 1981, Blaisdell et al. 1982, Bradley et al. 1992).

\begin{tabular}{|c|c|c|}
\hline Species & Fire & $\begin{array}{c}\text { Herbicide } \\
\text { 2,4-D }\end{array}$ \\
\hline Achillea millifolium $\mathrm{L}$. & $\mathrm{O}+$ & $\mathrm{O}-\mathrm{U}+$ \\
\hline Agoseris spp. & $\mathrm{U}$ & $\mathrm{O}$ \\
\hline Allium accuminata Hook. & $\mathrm{U}$ & \\
\hline Antennaria spp. & $\mathrm{O}-\mathrm{U}$ & $\mathrm{O}$ \\
\hline A. (mat spp.) & $\mathrm{S}$ & $S$ \\
\hline Aster spp. & $\mathrm{U}+$ & $\mathrm{O}-\mathrm{U}+$ \\
\hline Astragalus spp. & $\mathrm{O}-\mathrm{U}$ & S-U \\
\hline A. purshii Hook. & $\mathrm{O}$ & $\mathrm{O}$ \\
\hline Balsomorhiza spp. & $\mathrm{U}+$ & $S$ \\
\hline Castilleja spp. & $\mathrm{U}$ & $S$ \\
\hline Crepis spp. & $\mathrm{O}+$ & $\mathrm{U}$ \\
\hline Erigeron spp. & $\mathrm{U}$ & $\mathrm{O}$ \\
\hline Eriogonum spp. & $\mathrm{S}$ & $\mathrm{U}$ \\
\hline Geranium spp. & $\mathrm{O}+$ & $\mathrm{O}-\mathrm{U}$ \\
\hline Geum spp. & $\mathrm{O}-\mathrm{U}$ & $\mathrm{S}$ \\
\hline Lactuca serriola $\mathrm{L}$. & $\mathrm{O}-\mathrm{U}$ & $\mathrm{O}-\mathrm{U}$ \\
\hline Lomatium spp. & $\mathrm{U}$ & $\mathrm{O}$ \\
\hline Lupinus spp. & U+ & $S$ \\
\hline Mertensia spp. & $\mathrm{O}-\mathrm{U}$ & S \\
\hline Microsteris gracilis Hook. & $\mathrm{U}$ & $\mathrm{O}$ \\
\hline Penstemon spp. & 0 & $\mathrm{~S}-\mathrm{O}$ \\
\hline Phlox longifolia Nutt. & U+ & $\mathrm{O}$ \\
\hline P. hoodii Torry \& A. Gray & $\mathbf{S}$ & $\mathrm{O}-\mathrm{U}+$ \\
\hline Potentilla spp. & U+ & $\mathrm{S}-\mathrm{O}$ \\
\hline Senecio intergerrimus Nutt. & $\mathrm{O}$ & $\mathrm{O}$ \\
\hline Solidago spp. & $\mathrm{U}$ & $\mathrm{U}$ \\
\hline Taraxicum spp. & $\mathrm{U}$ & $\mathrm{O}$ \\
\hline Tragopogon dubius Scop. & $\mathrm{O}$ & U+ \\
\hline Trifolium macrocephalum Pursh & $\mathrm{U}$ & $\mathrm{S}$ \\
\hline Zigadenus paniculatus Nutt. & & $\mathrm{S}$ \\
\hline
\end{tabular}

${ }^{a} \mathrm{~S}=$ Severely Damaged, $\mathrm{O}=$ Zero to Slight Damage, $\mathrm{U}=$ Undamaged, + = increases, - = declines.

exhibit rapid recovery following fire. Annual and biennial forbs usually increase following fire through seed dispersal mechanisms. However, forbs that are suffrutescent, low growing, or mat forming such as pussytoes (Antennaria spp. Gaertner) or several of the buckwheats (Eriogonum spp. Michx.) can be severely damaged by fire (Table 3 ). Big and low sagebrush and young juniper are easily killed by fire (Blaisdell 1953, Burkhardt and Tisdale 1976, Wright and Bailey 1982).

Reestablishment of sagebrush in burned sites is highly variable and dependent on nearby seed sources or seed reservoirs produced during the previous growing seasons in addition to weather conditions following the fire (West and Yorks 2002). Dispersal of sagebrush seed is limited to several meters from the parent plant. Reestablishment generally occurs more rapidly in the more mesic big sagebrush communities. Generally, shrub cover can reach or exceed preburn levels in as little as 20 years but more typically within 25-45 years (Watts and Wambolt 1996, Wambolt et al. 2001). A MFRI of less than 50 years in mountain big sagebrush communities and 100 years in low sage- woodlands will continue to expand (Betancourt 1987, West and Van Pelt 1986, West 1999a, Miller et al. 2000). Where juniper gains dominance in mountain big sagebrush communities, shrub cover declines to $<1 \%$ (Miller et al. 2000) and the season of available succulent forbs is shortened because of rapid soil moisture depletion (Bates et al. 2000). On warmer, drier sites, high intensity crown fires may cause woodlands with depleted understories to transition to annual dominated communities (Tausch 1999; Fig. 3 and 4)

The second scenario, which has most extensively occurred in the Wyoming big sagebrush cover type, is the invasion of annual grasses. Invasion by exotic annuals has resulted in dramatic increases in both size and frequency of fire (Young and Evans 1973, Whisenant 1990, Swetnam et al. 1999, Tausch 1999, West 2000). For example, Whisenant (1990) reported MFRI in Wyoming big sagebrush communities has been reduced from 50-100 years to $<10$ years. Repeat fires have allowed cheatgrass and other introduced annuals to replace the native shrub and herb layers. As early as the 1930s, range managers were aware of the rapid invasion of cheatgrass following fire (Stewart and Hull 1949). Cheatgrass now dominates or has a significant presence on 6.9 million ha of Great Basin rangeland (Pellant 1994), and over much of this area, annual-dominated communities can be considered a new steady state (Laycock 1991). These fine fuels shift fire seasonality to the more active growing period of native perennials (Whisenant 1990). The end results are that herbaceous cover varies greatly from year to year depending on moisture availability, shrub cover is absent, the season of available green plant material is shortened, high quality perennial forbs are scarce, and forage is absent in late summer through winter.

Risk of invasion by Mediterranean annuals in Wyoming and basin (Artemisia tridentata ssp. tridentata Nutt.) big sagebrush communities increases below elevations of $1500 \mathrm{~m}$ and becomes extreme below $1000 \mathrm{~m}$. Exotic annual grasses such as cheatgrass will not usually dominate more mesic and cooler sagebrush types characterized by mountain big sagebrush and low sagebrush. Wyoming big sagebrush growing on old parent materials (low nutrient status, e.g., West and Yorks 2002) and colder sites, such as the high deserts in central Nevada, southern Utah, and southwestern Wyoming, also appear to be more resistant to cheatgrass invasion. Colder temperatures lower and delay ger- 
Pre-Settlement

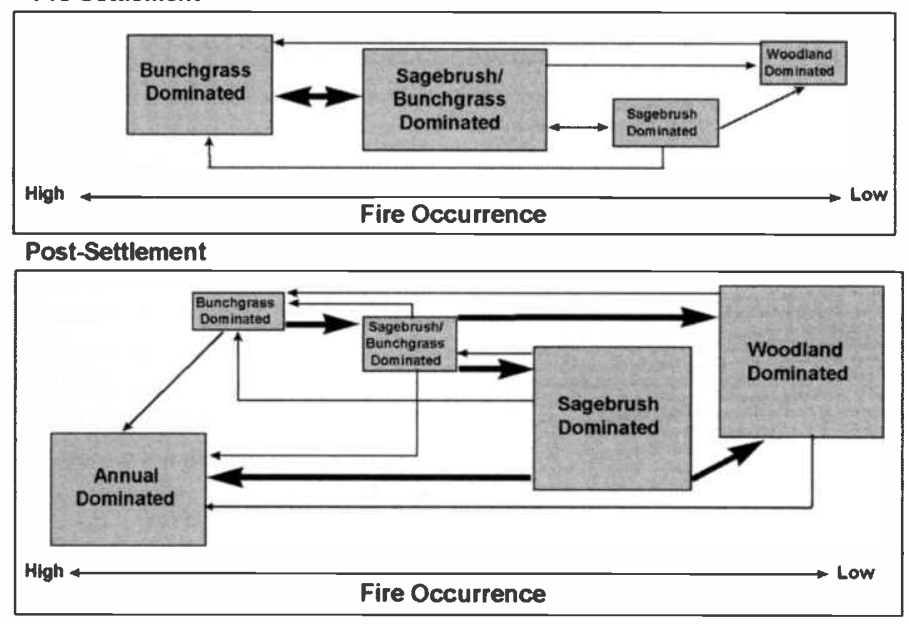

Fig. 3. Conceptual model illustrating pre and post-European settlement shrubland and woodland dynamics. Changes in box sizes represents shifts in area occupied by the different cover types. Heavy arrows indicate most common successional pathways. Adapted from Miller and Tausch 2001.

mination and slow down phenological development of cheatgrass. Competition from native herbaceous species may also be greater in these cooler and more mesic plant communities. Cheatgrass usually fares poorly in black sagebrush communities. Medusahead (Taeniatherum asperum Simonk.), however, can become abundant on some low sagebrush sites below $1500 \mathrm{~m}$, especially where clay content is high (Dahl and Tisdale 1975, West and Young 2000).

Secondary weed species such as squarrose knapweed (Centaurea squarrosa Willd), rush skeleton weed (Chondrilla juncea L.), and bur buttercup (Ranunculus testiculatus Crantz) are rapidly invading cheatgrass and native plant communities in the Intermountain West, especially on ecological sites where Wyoming big sagebrush once dominated. Squarrose knapweed, like cheatgrass, produces an abundance of fine fuels. Continued spread of these secondary weeds shortens fire return intervals, increases the homogeneity and size of fires across the landscape, and threatens the integrity of Wyoming big sagebrush habitat.

\section{Implications to sage-grouse and research needs}

A limited number of studies have produced mixed reports on the impact of fire on sage-grouse populations (Rowland and Wisdom 2002). This is not entirely surprising given that the impact of fire on sage-grouse habitat is contingent on a large number of factors, including site potential, ecological condition, limiting functional plant groups, and the pattern, size, and season of burning. Additionally, most studies investigating the effects of fire on sage-grouse have been short-term (<10 years) (e.g., Bensen et al. 1991, Fischer et al. 1996). The lag response of sage-grouse combined with the long time periods typically needed by sagebrush to reestablish after fire, suggest that the ultimate evaluation of impacts of fire on sagegrouse habitat is to determine long-term use of burned and unburned areas, as well as periodic evaluation of plant community structural diversity over time, since burned areas will change in habitat suitability over time.

The impact of fire on the structure and composition of sage-grouse habitat may be positive or negative. Fire can enhance native perennial forbs and grasses, particularly where sagebrush is abundant, good populations of native herbs are present, and exotic species are limited. This most often applies to mountain big sagebrush communities where shrub canopy cover can exceed $35 \%$ and perennial forbs can increase 2 to 3 fold following fire (Blaisdell 1953, Miller unpublished data). However, the response of perennial forbs and grasses following fire can be highly variable (Harniss and Murray 1973, Nelle et al. 2000). Fire can lengthen the growing season for forbs important to sage-grouse (Wrobleski 1999), enhance the nutrient quality of forbs (McDowell 2000), and sage-grouse have been reported to be attracted to burned areas during the broodrearing period (Klebenow and Beall 1977, Martin 1990). Limited research indicates

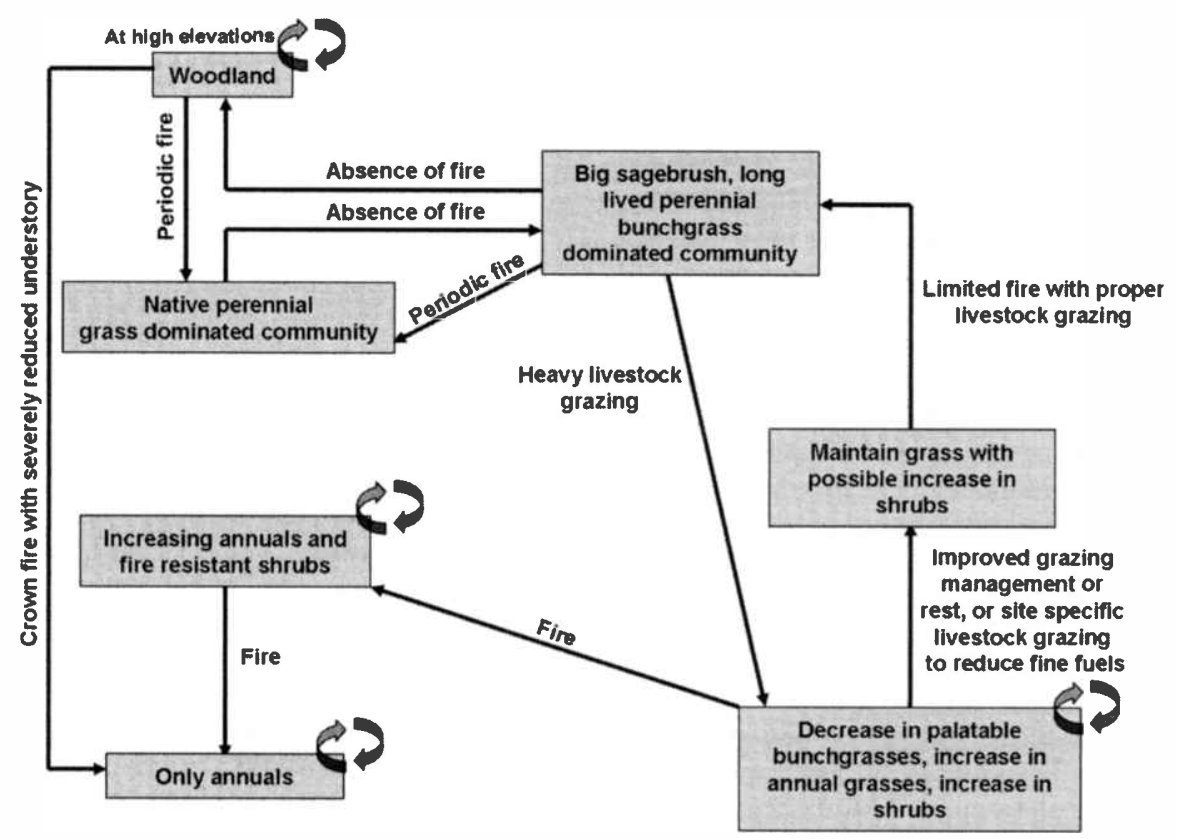

Fig. 4. Hypothesized relationship of grazing and fire to successional dynamics in sagebrush plant communities. Curved arrows indicate potentially steady states requiring management intervention to change community type to one more desirable for sage-grouse habitat. Movement to annual-dominated communities predominantly occurs in Wyoming big sagebrush (Artemisia tridentata ssp. wyomingensis Welsh) and at elevations below $1500 \mathrm{~m}$, but can occur following crown fires in woodlands with severely depleted understories. The specific elevation for transitional thresholds to annual or woodland communities will vary regionally. Adapted from West 1989. 
that ants and beetles initially increase with fire in mountain big sagebrush communities but are not affected long-term (Nelle et al. 2000). Periodic fires with intervals less than 50 years will prevent negative habitat effects associated with pinyon and juniper encroachment into shrub steppe communities (Miller and Tausch 2001). In areas where grasses and shrubs have been drastically reduced or eliminated due to conifer dominance, mechanical pre-treatment of conifers can be used to promote fine fuel production. In addition, prescribed fires can break up fuel continuity, reducing the threat of future large and more complete burns.

Negative impacts of fire on sage-grouse habitat may include removal, at least temporarily, of the sagebrush overstory, thus decreasing the value of affected communities as winter and nesting habitat. In Wyoming big sagebrush dominated communities, there is little evidence that fire will enhance sage-grouse habitat where there is already a balance of native shrubs, perennial grasses, and forbs. Burning in these communities does not significantly increase desirable forbs used as sagegrouse food (Fischer et al. 1996, Miller unpublished data) and abundance of beetles (Hymenoptera), an important chick food (Pyle and Crawford 1996), may decrease (Fischer et al. 1996) or be unaffected (Pyle and Crawford 1996). Fire should not be used where sagebrush cover is the limiting factor for sage-grouse or where introduced annuals have replaced native perennial forbs and grasses. When deciding whether to burn on arid/low elevation sites, or in the Wyoming big sagebrush cover type, managers must balance the desired mix of plant communities with local assessments of the ability of shrubs to re-establish post-fire, and the potential for fire-induced annual grass dominance. In addition, some herbaceous species such as Idaho fescue (Festuca idahoensis Elmer) are sometimes decreased by fire and can require long time intervals for recovery (Wambolt et al. 2001). The amount of less palatable shrubs that resprout [rabbitbrush, horsebrush (Tetradymia spp. DC.), and broom snakeweed (Gutierrezia sarothrae Lag.)] should also be considered. These species typically increase following a burn but may be replaced by sagebrush in the absence of frequent disturbances (Young and Evans 1974). The impact of fire on the ecology of other Artemisia species, such as mid to high elevation silver sagebrush (Artemisia cana Pursh) communities, is not well understood.

The goal of managing sage-grouse habitats for an optimal balance of shrubs, forbs, and grasses at community and land- scape scales should be analogous with restoring and or maintaining form, function, and process in sagebrush-dominated habitats. However, many questions remain regarding the impact of fire on sagegrouse habitat. For instance there is only limited documentation on the rate, variability, and environmental factors affecting sagebrush re-establishment in burns, and post-fire restoration of native herbaceous and shrub species in lower-elevation sagebrush communities has met with only limited success. The importance of successful restoration increases in proportion to the likelihood of post-fire annual grass invasion. The spatial and temporal effects of fire at landscape scales has received only limited attention, and should be addressed in concert with determining the landscape-scale mosaic of seral stages that provides optimal habitat for sage-grouse.

\section{Livestock grazing}

Livestock grazing has been extant in sagebrush plant communities for more than a century. However, only a few studies have directly addressed the effects of livestock grazing on habitat use by sagegrouse. Consequently, rangeland and wildlife managers must rely, with caution, on indirect evidence for guidance. Livestock grazing may affect sage-grouse habitat directly by altering structural habitat factors or plant community composition, or indirectly by altering abiotic processes (e.g., MFRI) and invasibility of sagebrush plant communities. While the impact of grazing on sagebrush plant communities varies with site potential, ecological condition, and climate variables, the aspects of livestock grazing that are controlled by management are, principally, the timing and intensity of defoliation.

\section{Livestock grazing history}

Herbivory as a disturbance of sagebrush-dominated plant communities existed prior to the arrival of domestic livestock in sage-grouse habitat (Burkhardt 1996). However, the proliferation of domestic livestock in the latter 1800s represented a fundamental change in the diversity of dominant herbivores, and the timing, and selection pressures associated with herbivory (Miller et al. 1994). Historic grazing practices centered around season-long use with stocking rates far exceeding carrying capacity (Young and Sparks 1985). The net impact of these grazing practices on sagebrush-dominated plant communities was an increase in shrub abundance, a decrease in perennial grasses, and the proliferation of non-native annual grasses (Young et al. 1972, 1976).
By 1900 , cattle and sheep on western rangelands totaled over 30 million animals (Wagner 1978). Cattle and sheep AUM's on federal land declined since the early 1900s (Council for Agricultural Science and Technology 1974, Laycock et al. 1996) and decreased more than $25 \%$ in the last 40 years (USDI-BLM 1990). Concurrent with reduced stocking of public rangelands has been measurable improvements in range condition during the latter half of the 1900s (Box 1990, Laycock et al. 1996).

\section{Timing and intensity of livestock grazing}

Research suggests that moderate livestock grazing or less in mid to late summer, fall, or winter is generally compatible with the maintenance of perennial grasses and forbs in sagebrush habitat (Pechanec and Stewart 1949, Mueggler 1950, Laycock and Conrad 1967, 1981, Gibbens and Fisser 1975, Miller et al. 1994, Bork et al. 1998). Herbaceous species in sagebrush plant communities are predominantly cool-season (C-3) plants that are vulnerable to defoliation during late spring and early summer. Heavy grazing (approximately $60 \%$ or greater utilization by weight) during this time has predictable results: 1) the vigor, yield, and cover of late-seral grasses and forbs decrease; 2) early-seral species (including annual grasses) may increase; 3) sagebrush density and canopy cover may increase (Craddock and Forsling 1938, Pechanec and Stewart 1949, Mueggler 1950 , Laycock 1967, Bork et al. 1998); and 4) transition of sagebrush uplands to higher ecological status is inhibited (Mueggler 1950, Eckert and Spencer 1986, Laycock 1987; Fig 4.).

Moderate use has traditionally been defined as occurring within the range of 40-60\% utilization by weight, however, generalizing a specific level of utilization that represents "proper use" can be difficult (Caldwell 1984). These difficulties arise in part due to lack of consistency in measurement technique (Frost et al. 1994), and the variable impact of a given level of utilization on plant communities in accordance with plant species present, site conditions, and climate variables. Some perennial grasses, such as Indian ricegrass (Oryzopsis hymenoides (R. \& S.) Ricker), needle-and-thread (Stipa comata Trin. \& Rupr.), Nevada bluegrass (Poa nevadensis Vasey ex Scribn.), and Sandberg bluegrass, can withstand severe grazing (approximately $80 \%$ or greater utilization) as long as defoliation does not occur dur- 
ing the plants' reproductive period (Pearson 1964). Other grasses such as Idaho fescue, Thurber needlegrass (Stipa thurberiana Piper), and bottlebrush squirreltail (Sitanion hystrix (Nutt.) J.G. Smith) decrease with heavy grazing (Rickard et al. 1975, Eckert and Spencer 1987). Restoration of sites in poor ecological condition may benefit from reduced utilization (Holechek et al. 1999) or rest (Fig. 4). Additionally, grazing tolerance of sagebrush-dominated plant communities can decrease with drought conditions and increase in periods of above average precipitation (Westoby et al. 1989). When used in conjunction with other information sources (e.g., weather data, non-livestock sources of herbivory) utilization data can be a valuable tool for helping to interpret the influence of livestock herbivory on vegetation trend (Sanders 1998). However, utilization data are not a substitute for long-term vegetation monitoring, and management objectives should be based on desirable vegetation composition over time, not utilization guidelines (Sharp et al. 1994, Burkhardt 1997, Sanders 1998).

Cattle, sheep, and horses (Equus caballus) in sagebrush habitat eat grass-dominated diets in all seasons of the year (Severson et al. 1968, Harrison and Thatcher 1970, Mackie 1970, Uresk and Rickard 1976, Olsen and Hansen 1977, Reiner and Urness 1982, Krysl et al. 1984, Ngugi et al. 1992, Crane et al. 1997, Glidewell et al. 2001) although sheep may consume a higher percentage of their diet as forbs. Livestock usually consume little to no sagebrush $(<10 \%)$ unless snow depth exceeds $20 \mathrm{~cm}$ (Harrison and Thatcher 1970), but winter sheep use of low elevation basin big sagebrush may be much greater (Cook et al. 1954). Sheep grazing in fall favors production of perennial forbs, whereas spring grazing can decrease forb production (Bork et al. 1998). Reduced sagebrush canopy cover in fall-grazed pastures (Mueggler 1950, Laycock 1967, Bork et al. 1998) is caused largely by competition from healthy grasses and forbs, rather than fall livestock browsing of sagebrush (Wright 1970).

Sagebrush cover generally increases as utilization of the herbaceous understory increases (Wright and Wright 1948, Pechanec and Stewart 1949, Mueggler 1950, Laycock 1967, Bork et al. 1998). But, once sagebrush cover reaches an upper threshold, livestock exclusion may have little effect on reversing the immediate trend (Johnson and Payne 1968, Rice and Westoby 1978, Sanders and Voth 1983, Wambolt and Payne 1986). Over long time intervals (40 years or more), sagebrush abundance may decline with a concomitant increase in understory herbaceous species (Anderson and Inouye 2001). On Wyoming big sagebrush sites with dense sagebrush and an understory of annual grasses, reductions in livestock grazing can hasten further habitat degradation if ungrazed fuel loads promulgate wildfires that burn uniformly and kill sagebrush on vast areas (Peters and Bunting 1994, West 1999b; Fig. 4).

Timing of grazing greatly influences the effects of livestock grazing in meadows and riparian areas. These sites are particularly vulnerable in late summer when excessive grazing and browsing may damage riparian shrubs, reduce the yield and availability of succulent herbs (Kovalchik and Elmore 1992), and cause deterioration of riparian function over time (Klebenow 1985). However, moderate utilization by livestock in spring, early summer, or winter is sustainable in non-degraded meadow and riparian areas within sagebrush habitat (Shaw 1992, Clary et al. 1996, Mosley et al. 1997). Moderate use equates to a 10$\mathrm{cm}$ residual stubble height for most grasses and sedges and 5-cm for Kentucky bluegrass (Mosley et al. 1997, Clary and Leininger 2000). Shrub utilization should not exceed $50-60 \%$ during the growing season, and at least $50 \%$ protective ground cover (i.e., plant basal area + mulch + rocks + gravel) should remain after grazing (Mosley et al. 1997). While hydrophytic shrubs may not directly serve as sage-grouse habitat, they do impact the stability of riparian and meadow habitats important to sage-grouse (Winward 2000). The length of time livestock have access to meadows may be more important than the level of utilization; it has been suggested that livestock access be limited to $<3$ weeks (Myers 1989, Mosley et al. 1997). In riparian and meadow habitat degraded by heavy livestock utilization, rest from grazing may be necessary for recovery (Clary and Webster 1989).

\section{Implications to sage-grouse and research needs}

It is probably safe to assume that historic grazing practices had strong negative impacts on sage-grouse habitat and perhaps populations (Patterson 1952, Wallestad 1975, Beck and Mitchell 2000), although definitive historical population data do not exist. However, research directly addressing the population-level impact of current livestock grazing practices on sage-grouse is lacking (Connelly et al. 2000). As noted previously, livestock
AUM's have decreased and range condition has increased on federal lands since the mid 1900's, however, there has not been a concomitant increase in sagegrouse populations during the same time interval. This does not necessarily indicate a lack of association between grazing and sage-grouse populations, given that

1.) "improved" range condition (mainly increases in perennial bunchgrass abundance) associated with better livestock management practices may or may not equate to improvement in all habitat needs of sage-grouse,

2.) those plant communities displaying steady state dynamics may not change linearly with reduced stocking,

3.) it is unknown what portion of the areas with reduced stocking represent critical sage-grouse habitat, and

4.) the complicated nature of sagegrouse population dynamics may preclude their short-term response to management activities. Additionally, there has also been continued habitat loss through other factors (e.g., annual grass invasion, juniper encroachment, cultivation, road construction, powerline development, etc.).

A recent modeling exercise (Wisdom et al. 2002) incorporated 50 and $100 \%$ reductions in the detrimental effects of livestock grazing into a population level model for sage-grouse in the Interior Columbia Basin. The model predicted improved performance of sage-grouse populations with a combination of active habitat restoration and reduced livestock stocking rate, and equated reductions in livestock stocking rate to decreased detrimental effects of livestock on sage-grouse habitat at a 1 to 1 ratio. While this approach may appear empirically appealing in that it allows "what if" scenario modeling, caution is merited when assuming that reductions in livestock stocking rate are in a constant 1 to 1 ratio with changes in sage-grouse habitat quality, given that the exact slope of this relationship is unknown (it may be substantially greater or less than 1) and is variable in accordance with timing and intensity of livestock grazing, environmental factors, and specific type of sage-grouse habitat (e.g., nesting, brood-rearing, etc.). Given the complexity of the successional dynamics of sagebrush plant communities, combined with the multivariate nature of the effects of livestock grazing on these plant communities, it remains difficult to draw large-scale (time and space) conclusions regarding the impact of current livestock grazing practices on sage-grouse populations.

Livestock grazing may positively or negatively affect the structure and compo- 
sition of sage-grouse habitat. Brood-rearing habitat may be enhanced by grazing practices that favor upland forb production (e.g., fall grazing) and prescribed light $(<40 \%)$ to moderate spring grazing can remove standing herbage and make forbs more accessible (Smith et al. 1979, Fulgham et al. 1982). However, consumption of forbs by livestock may limit their availability to sage-grouse (Call 1979). In riparian brood-rearing habitat, sage-grouse prefer the lower vegetation $(5-15 \mathrm{~cm}$ vs. 30-50 cm; Oakleaf 1971, Neel 1980, Klebenow 1982, Evans 1986) and succulent forb growth stimulated by moderate livestock grazing (Neel 1980, Evans 1986). Prescribed livestock grazing in spring and early summer, especially by sheep and goats (Capra hircus), can help control invasive weeds (Mosley 1996, Olson and Wallander 2001, Merritt et al. 2001) and woody plant encroachment (Riggs and Urness 1989) in sage-grouse habitat and may reduce wildfire risks to low elevation plant communities. However, the logistics of applying such grazing treatments at large spatial scales remain difficult.

Excessive livestock grazing has negatively impacted sage-grouse habitat by creating seral conditions that favor annual grass dominance and by reducing perennial grasses used as nesting and escape cover (Beck and Mitchell 2000). However, the specific relationship between grazing pressure and sage-grouse nest success has not been empirically evaluated. Heavy use of riparian meadows by livestock reduces the availability of succulent plant species and may induce avoidance of these habitats by sage-grouse (Neel 1980, Klebenow 1982, 1985). Nest destruction by livestock trampling is rare, however, the presence of livestock can cause sage-grouse to abandon their nests (Rasmussen and Griner 1938, Patterson 1952, Call 1979). Managers should consider delaying grazing of known nesting areas until after nesting (Beck and Mitchell 2000).

Rotational grazing systems are one way to provide areas (i.e., pastures) free from livestock disturbance during nesting. This benefit may be offset if heavy use occurs in the grazed pastures (Holechek et al. 1982), especially since sage-grouse can display high site fidelity (Fischer et al. 1993). One advantage of rest rotation grazing is that rested pastures can provide emergency forage (Ratliff and Reppert 1974), which may prevent excessive grazing in the used pastures during drought. This added residual cover may be important to sage-grouse, but light to moderate utilization of grasses in well-managed continuously grazed systems may also provide sufficient residual cover. Grazing systems in riparian areas have met with mixed results and their influence on system recovery and vegetation response will vary based on site potential, ecological condition, stream morphology, and climate (Elmore and Kauffman 1994). Compared with no grazing, rest rotation grazing increased forb abundance on sage-grouse meadow habitat in Nevada (Neel 1980).

Additional research is needed to address the direct effects of livestock grazing management on sage-grouse. Given the limited research base, much of what needs to be done is basic in nature. For example, research is needed to examine the effects of grazing variables such as timing, intensity, frequency, and stock density on sagegrouse habitat use patterns, nest success, and population dynamics. Additionally, research should continue to address the impacts of livestock grazing on patterns of plant succession at multiple space and time scales. This research should include both direct effects, as well as the interactive effects of grazing and abiotic factors (e.g., fire frequency) on plant succession.

\section{Herbicide}

Control of sagebrush has impacted large portions of rangeland in the western U.S. By the 1970's, over 2 million ha of sagebrush had been mechanically treated, sprayed, or burned (Schneegas 1967, Vale 1974). This practice has been widely associated with declines in sage-grouse habitat quality (Connelly et al. 2000). Much of the research literature has focused on maximum sagebrush kill in strips or blocks, but recent work has examined the impact of selective thinning of sagebrush on wildlife habitat quality (Baxter 1998).

Where sagebrush density is high enough to limit understory expression of forbs and grasses, some reduction of sagebrush may be desirable (Laycock 1991). Initial efforts to control sagebrush used 2,4-D [(2,4dichlorophenoxy) acetic acid], which was effective in suppressing big sagebrush and typically resulted in dramatic increases in herbage production (Orpet and Fisser 1979, Waltenberger et al. 1979, Kearl and Freeburn 1980). The impact of 2,4-D on forb abundance varies by species (Table 3 ). Concerns over reduced plant diversity following 2,4-D have severely limited its use. Tebuthiuron (N-[5-(1,1-dimethylethyl)1,3,4-thiadiazol-2-yl]-N,N'-dimethylurea), a photosynthesis inhibitor with soil activity greater than 1 year, was introduced in 1973 and can selectively control big sagebrush at low application rates. Recent studies have demonstrated that big sagebrush canopy cover is reduced in proportion to application rate, with simultaneous progressive increases in understory grass and forb abundance (Whitson and Alley 1984, Whitson et al. 1988, Halstvedt 1994, Olson et al. 1994, 1996, Johnson et al. 1996, Olson and Whitson 1996, 2002). For example, Halstvedt et al. (1996) reported a $59-491 \%$ increase in native perennial grass production following reduction of pre-treatment big sagebrush canopy cover $(25-35 \%)$ to $12-15 \%$ after 10-17 years following tebuthiuron thinning treatments. Forb production increased between $15-127 \%$ on treated sites. Herbicides offer some advantages to mechanical manipulation of sagebrush including cost effectiveness, longer treatment life, less damage to non-target shrub species, decreased erosion risk, and better control of the extent of sagebrush kill (Blaisdell et al. 1982, Olson et al. 1994, Baxter 1998).

\section{Implications to sage-grouse and research needs}

Block or strip applications of herbicide at rates that severely diminish sagebrush will likely have negative impacts on sagegrouse habitat quality. In lekking habitat, some researchers report decreases in sagegrouse males following sagebrush removal (Wallestad 1975, Connelly et al. 1981), while others have found no clear effect (Gates 1985, Martin 1970, Benson et al. 1991, Fischer 1994). Sage grouse may cease to use block treated areas as nesting habitat (Klebenow 1970) and winter habitat degradation is proportional to severity of sagebrush kill (Connelly et al. 2000). Increases in forb availability in strip or block-sprayed habitat may increase the value of these areas as brood-rearing habitat (e.g., Autenrieth 1969) but use patterns often indicate avoidance of treated areas (Klebenow 1970, Braun et al. 1977).

It has been suggested that thinning treatments can be used as a tool to manage sage-grouse habitat (Beck and Mitchell 2000). Lekking habitat is rarely limited, but in areas where dense, monotypic big sagebrush stands limit suitable lekking grounds, sagebrush thinning can create small open areas for breeding activities. Sage-grouse have been reported to use newly disturbed sites as leks (Connelly et al. 1981). In localized areas, reduced application rates of tebuthiuron can be used to thin big sagebrush cover and 
increase understory perennial grasses and forbs associated with nesting and broodrearing habitat. Thinned Wyoming big sagebrush stands may have maximum forb production at 11 to $17 \%$ sagebrush canopy cover (Johnson et al. 1996). Where sagegrouse winter cover is limited, thinning of big sagebrush should be avoided (Klebenow 1985, Robertson 1991). Connelly et al. (2000) recommended that treatments be limited to $<20 \%$ of the breeding habitat (depending on sagebrush type) within a 20 to 30 -year period, primarily because of concerns over damage to winter habitat. Additional research is needed to further identify the impact of sagebrush thinning on habitat use by sage-grouse.

Herbicides can also be used to control invasive annual plant species in sagegrouse habitat. For instance, herbicides may be useful in controlling cheatgrass abundance (Mosley et al. 1999, Pellant et al. 1999). Herbicides such as imazapic (Plateau) applied prior to cheatgrass emergence can be used to release forbs and perennial grasses in the understory (Whitson 2003). Herbicide control of cheatgrass has positive implications to the maintenance of communities in danger of transitioning to annual-dominated states, and, when used in conjunction with native grass seeding, the restoration of sites that have already realized that transition. This latter practice has been suggested as a form of active restoration of sage-grouse habitat degraded by annual grass dominance (Hemstrom et al. 2002).

\section{Landscape issues in sage-grouse management and research}

The foregoing outlines, 1) the relatively complex life cycle of sage-grouse; 2 ) the collective observations of the bird in the many different kinds of habitat it requires throughout the year; and 3) different ways that individual birds and populations can be affected by abiotic, biotic, and management factors. It is important to realize that this information has been accumulated piecemeal (i.e., by many different people working in different places and at different times). Thus, compositing this information to form our understanding and creating guidelines for management (e.g., Connelly et al. 2000) is based largely on data taken from small areas over short times. This process may give a deceptive picture, both generally and specifically, for any given population. For instance, there may be differing causes of mortality in different places, at different times, particularly between migratory and resident populations. Some of the studies could involve shrinking populations, whereas others could involve stable to growing populations. The type of population present in each study needs to be identified because they require different types of management responses.

It is now apparent that rather than one, a few to many causes may be synergistically and cumulatively operating to diminish sage-grouse. For instance, reducing predator control may occur simultaneously with undesirable changes in vegetation structure triggered by other factors (e.g., livestock grazing practices, fire control). While many believe that cause and effect mechanisms need to be disentangled for declining sage-grouse populations, others judge that to be neither feasible nor timely. ShraderFrechette and McCoy (1993) emphasize that solving complex issues, like sustaining sage-grouse populations, will be more tractable in a case study mode.

\section{Linking habitat and population changes}

Researchers and managers have long had a vague, qualitative notion that sagegrouse respond to negative changes within entire landscapes (Connelly et al. 2000), portions of which the birds use at various times of the year. Until recently, however, a ready means of quantifying landscape patterns and change was lacking. Now, geomatics [combined remote sensing (RS), global positioning systems (GPS), and geographic information systems (GIS)], can be employed to give quantitative expressions and visualizations of habitat patterns over large areas of land for the past several decades. Landscape ecology (Turner et al. 2001) provides a logical framework and a new set of tools to examine how spatial arrangements of different kinds of habitat may influence individuals and populations. Intermediate-sized landscapes of 250,000 to 2.5 million ha and their macro-mosaics of ecological sites and stands in various seral stages seem to be the most appropriate scale for management solutions to be successful, since improvements in only part of the year-round habitat may be negated by degradation in other nearby habitat needed at other times. Successful management at the scale of the entire geographical range of the species is unlikely because all races of sage-grouse may not have the same habitat requirements or respond to environmental changes and management in identical ways.

By combining landscape ecology and geomatics, it is now possible to characterize both current spatial patterns and changes in these geographic patterns over about the past 50 years by analyzing archived imagery. Data coverage of entire landscapes in the range of 100,000 to 250,000 ha is now feasible, as illustrated in the recent work of Washington-Allen (2003) at the Deseret Ranch in northeastern Utah. Patches of land can be characterized as to cover dominance by plant growth forms and bare ground. Fragmentation and coalescence, patch sizes and boundary shapes and proximity to similar and dissimilar patches can be tracked over time. Underlying GIS layers dealing with management and disturbance history, along with soils, ecological site [as provided by Natural Resource Conservation Agency (NRCS) databases] and seral status can be connected to indicators of sage-grouse abundance. A similar approach at large scales $\left(1 \mathrm{~km}^{2}\right.$ pixels) was recently used to characterize habitat changes in the Interior Columbia Basin (Hemstrom et al. 2002).

Sage-grouse is not a species that can thrive only where large homogeneous stands of any single plant species occupy the bulk of the landscape. While recommendations exist for the kinds of habitats that are preferred at different times in the life cycle of the bird (Connelly et al. 2000 ), the proportions of habitats that are optimum or even tolerable remains unknown. It is likely that sage-grouse are responding to habitat attributes at multiple scales while other sagebrush obligates may be responding at different scales. These questions can now be addressed by applying concepts from landscape ecology linked through geomatics technology. This will allow natural resource professionals to break away from their traditions of collecting only short runs of point-based data focused on either livestock or wildlife species and the plant communities in which they are found.

We suggest that areas where sagegrouse have recently diminished be collectively identified. From archived aerial photos and satellite imagery, fundamental changes in the landscape can be quantified via time series of landscape metrics (Turner et al. 2001) and other RS/GIS based indicators (Washington-Allen 2003). Another useful effort would be to characterize and compare the landscapes holding non-migratory populations to those that are migratory. The existence of non-migratory populations implies that all habitat requirements of sage-grouse are sometimes met in one relatively small area. In these areas, the mix of habitats 
and their proportions needs to be defined. Similar studies involving lesser prairie chickens (Tympanuchus pallidicinctus) have suggested some factors that land managers can pro-actively address (Woodward and Fuhlendorf 2001).

The approach suggested above will require a level of collaboration rarely seen between landscape ecologists and wildlife and range scientists. Many different landowners and managers will need to be involved because landscapes frequently cross ownership and political boundaries. Non-governmental organizations such as the North American Grouse Partnership could serve to facilitate such activities crossing jurisdictional boundaries. The Western Association of Fish and Wildlife Agencies should also foster such work, promoting cooperation between states and ecologists and managers with broad expertise.

Another aspect that needs to be addressed frontally is the choice of how and what to study. If the details of quantification of various aspects of environment and biota (e.g., sagebrush cover, Miller et al. 2003) are not agreed upon from the outset, time and trust will be dissipated during the inevitable arguments about interpretation of results. Because the sage-grouse issue is of regional concern, it needs to be approached in a multi-state fashion. If different states and other jurisdictions take differing approaches, arguments about the confoundments of place, times, and methods might persist interminably.

\section{Some Final Thoughts}

Management of sage-grouse populations and their habitat is set within the political and sociologic tendency to focus on individual pieces of the overall management challenges. However, the ecology and management history of sage-grouse and their habitat combine to suggest a more complex, multivariate relationship, and to focus on any single issue (e.g., livestock grazing, fire regime, other land management practices, disease, predation) is to deny the complexity of the overall situation. The take home message is that solutions will involve a diversity of management and research professionals working in concert to solve multifaceted problems.

In a broader spatial and temporal context, the sage-grouse decline may be symptomatic of long-term regional level problems. While sage-grouse are currently at the center of ecological and political concern, other species, mainly sagebrush obligates [e.g., Brewer's sparrow (Spizella pallida), pygmy rabbit (Brachylagus idahoensis), sagebrush vole (Lagurus curtatus)], are also declining, suggesting that "fixing" the sage-grouse problem should be synonymous with improvements at the ecosystem level. This point may be of particular importance given the burgeoning number of local and state-level sagegrouse working groups in the western US. If system level problems are not addressed now, the efforts of these working groups will have to be repeated for other sagebrush obligates, as additional species take political front and center over time. Regional level dialogue and planning should be facilitated by the Interagency Sage Grouse Conservation Framework Team, which provides an effective linkage between state level conservation efforts. Access to the data needed to make large-scale decisions has been aided by the SAGEMAP project (http://sagemap.wr.usgs.gov), which serves as a storehouse for spatial data pertaining to conservation of sage-grouse and sagebrushdominated plant communities.

Natural resource professionals of all walks should strive to keep an open mind regarding the potential structure of plant communities serving as sage-grouse habitat. A good example is the amount of sagebrush cover a given community can be expected to produce. It is quite probable that differences of opinion on this matter are due to differences in vegetation sampling methodology. In such cases, published ecological site information can be a useful intermediary for helping find common ground (e.g., NRCS data, Tisdale et al. 1965, Winward 1970, Mueggler and Stewart 1980). Natural resources professionals should also consider that without purposeful habitat management (e.g., prescribed fire-based juniper control) successional changes may decrease the value of some plant communities as sage-grouse habitat. Active management will likely be required to address the problem of annual grass invasion in sage-grouse habitat; a dilemma for which there is not currently a definitive solution over large scales.

Bringing together groups of professionals (e.g., range and wildlife specialists) in an effective manner involves coordinated planning. One potential avenue of cooperation would involve re-visiting past sagegrouse research efforts. If the precise geographic locations of these projects could be obtained, rangeland scientists could work in concert with wildlife scientists to identify big sagebrush subspecies and serally interpret the vegetation structure preferred by sage-grouse. This information could then be used as the basis of a succession-based model for predicting management impacts, and planning habitat manip- ulations. Such efforts must have active participation from both management and research entities; without management buy-in, significant amounts of time and energy can be wasted developing models that will never be used. As was previously pointed out, this is not a process that will produce quick results. Instead, time is needed for management actions to produce changes in habitat and other environmental variables before the impacts on sagegrouse populations can be manifested. Thus, it is imperative that such efforts be initiated as soon as possible.

\section{Literature Cited}

Aldridge, C.L. 2000. Reproduction and habitat use by sage grouse (Centrocercus urophasianus) in a northern fringe population. M.S. Thesis, Univ. of Regina, Regina, Saskatchewan.

Aldridge, C.A. and RM. Brigham. 2002. Sage-grouse nesting and brood habitat use in southern Canada. J. Wildl. Manage. $66: 433-444$

Anderson, J.E. and RS. Inouye. 2001. Landscape-scale changes in plant species abundance and biodiversity of a sagebrush steppe over 45 years. Ecol. Monogr. 71:531-556.

Andrén, H. and P. Angelstam. 1988. Elevated predation rates as an edge effect in habitat islands: experimental evidence. Ecol. 69:544B547.

Angelstam, P. 1986. Population dynamics in tetraonids: the role of extrinsic factors. Proc. of the Int. Ornithological Cong. 19:2458B2477.

Autenrieth, R.E. 1969. Impact of strip spray on vegetation and sage grouse use on summer habitat. Proc. of the Western States Sage Grouse Workshop 6:147-157.

Autenrieth, R.E. 1981. Sage grouse management in Idaho. Ida. Dept. Fish \& Game.Wildl. Bull. 9. Boise, Ida.

Barnett, J.K. 1992. Diet and nutrition of female sage grouse during the pre-laying period. M.S. Thesis, Ore. St. Univ. Corvallis, Ore.

Barnett, J.K. and J.A. Crawford. 1994. Prelaying nutrition of sage grouse hens in Oregon. J. Range Manage. 47:114-118.

Bates, J.D., R.F. Miller, and T. Svejcar. 2000. Understory vegetation response and nitrogen cycling following cutting of western juniper. J. Range Manage. 53:119-126.

Batterson, W.M. and W.B. Morse. 1948. Oregon sage grouse. Oregon Game Comm. Oregon Fauna Serv. 1. Portland, Ore.

Baxter, G. 1998. Thinning dense sagebrush stands with Spike 20P. Rangelands 20:14-16.

Bean, R.W. 1941. Life history studies of the Sage Grouse (Centrocercus urophasianus) in Clark County, Idaho. B.S. Thesis, Ut. St. Agr. Coll. Logan, Ut.

Beck, T.D.I. and C.B. Braun. 1978. Weights of Colorado sage grouse. Condor 80:241-243.

Beck, J.L. and D.L. Mitchell. 2000. Influences of livestock grazing on sage grouse habitat. Wildl. Soc. Bull. 28:993-1002. 
Benson, L. A., C. E. Braun, and W. C. Leininger. 1991. Sage grouse response to burning in the big sagebrush type. Proc. of Issues and Technology in the Management of Impacted Western Wildlife, Thorne Ecological Instit. 5:97-104.

Betancourt, J.L. 1987. Paleoecology of pinyon-juniper woodlands: summary, p. 129-139. In: R.L. Everett (ed.) Proceedings: Pinyonjuniper conference. U.S.D.A. For. Serv., Gen. Tech. Rept. INT-215.

Blaisdell, J.P. 1953. Ecological effects on planned burning of sagebrush-grass range on the upper Snake River Plains. U.S.D.A. Tech. Bull. 1075. Washington, D.C.

Blaisdell, J.P., R.B. Murray, and E.D. McArthur. 1982. Managing inter-mountain rangelands-sagebrush-grass ranges. U.S.D.A., For. Serv., Gen. Tech. Rept. INT-134.

Blake, C.S. 1970. The response of sage grouse populations to precipitation trends \& habitat quality in south central Idaho. Proc. West. Assoc. State Game and Fish Commissioners. 50:452-462.

Bork, E.W., N.E. West, and J.W. Walker. 1998. Cover components on long-term seasonal sheep grazing treatments in three-tip sagebrush steppe. J. Range Manage. 51:293300.

Box, T.W. 1990. Rangelands, p. 101-120. In: R.N. Sampson, and W. Hair (eds.) Natural Resources for the 21 st Century. Island Press, Wash. D.C.

Bradley, A.F., N.V. Noste, and W.C. Fischer. 1992. Fire ecology of forests and woodlands in Utah. U.S.D.A., For. Serv., Gen. Tech. Rept. INT-287.

Braun, C.E. 1998. Sage grouse declines in western North America: what are the problems? Proc. of the West. Assoc. of St. Fish and Wildl. Agencies 78:139-156.

Braun, C. E., T. Britt, and R.O. Wallestad. 1977. Guidelines for maintenance of sage grouse habitats. Wildl. Soc. Bull. 5:99-106.

Browers, H.W. and L.D. Flake. 1985. Breakup and sibling dispersal of two sage grouse broods. Prairie Nat. 17:248-249.

Brown, D.E. and R. Davis. 1995. One hundred years of vicissitude: terrestrial bird and mammal distribution changes in the American Southwest, 1890-1990, p.231-244. In: L. F. DeBano, G. J. Gottfried, R. H. Hamre, C. B. Edminster, P. F. Ffolliott, and A. OrtegaRubio (tech. coordinators) Biodiversity and management of the Madrean Archipelago: the sky islands of southwestern United States and northwestern Mexico. U.S.D.A. For. Serv., Gen Tech Rept. RM-GTR-264.

Burkhardt, J.W. 1996. Herbivory in the Intermountain West. Univ. of Ida. For., Wildl. and Range Exp. Sta. Bull. 58.

Burkhardt, J.W. 1997. Grazing utilization limits: An ineffective management tool. Rangelands 19:8-9.

Burkhardt, J.W. and E.W. Tisdale. 1976. Causes of juniper invasion in southwestern Idaho. Ecol. 76:472-484.

Caldwell, M.M. 1984. Plant requirements for prudent grazing, p. 117-152. In: Nat. Res. Council/Nat. Acad. Sci. "Development
Strategies for Rangeland Management." Westview Press, Boulder, Colo.

Call, M.W. 1979. Habitat requirements and management recommendations for sage grouse. USDI-BLM Denver Serv. Center Tech. Note 330.

Call, M.W. and C. Maser. 1985. Wildlife habitats in managed rangelands: The Great Basin of southeastern Oregon: sage grouse. U.S.D.A. For. Serv., Gen. Tech. Rept. PNW187.

Clary, W.P. and W.C. Leininger. 2000. Stubble height as a tool for management of riparian areas. J. Range Manage. 53:562-573.

Clary, W.P. and B.F. Webster. 1989. Managing grazing of riparian areas in the Intermountain Region. U.S.D.A. For. Serv., Gen. Tech. Rept. INT-263.

Clary, W.P., N.L. Shaw, J.G. Dudley, V. A. Saab, J.W. Kinney, and L.C. Smithman. 1996. Response of a depleted sagebrush steppe riparian system to grazing control and woody plantings. U.S.D.A. For. Serv., Gen. Tech. Rept. INT-RP-492.

Connelly, J.W. and C.E. Braun. 1997. Longterm changes in sage grouse (Centrocercus urophasianus) populations in western North America. Wildl. Biol. 3:229-234.

Connelly, J.W., W.J. Arthur, and O.D. Markham. 1981. Sage grouse leks on recently disturbed sites. J. Range Manage. 34:153-154.

Connelly, J.W., H.W. Browers, and R.J. Gates. 1988. Seasonal movements of sage grouse in southeastern Idaho. J. Wildl. Manage. 52:116-122.

Connelly, J.W., M.A. Schroeder, A.R. Sands, and C.E. Braun. 2000. Guidelines for management of sage grouse populations and habitat. Wildl. Soc. Bull. 28:967-985.

Connelly, J.W., W.L. Wakkinen, A.P. Apa, and K. P. Reese. 1991. Sage grouse use of nest sites in southeastern Idaho. J. Wildl. Manage. 55:521-524.

Connelly, J.W., R.A. Fischer, A.D. Apa, K. P. Reese, and W.L. Wakkinen. 1993. Renesting by sage grouse in southeastern Idaho. Condor 95:1041-1043.

Connelly, J.W., K.P. Reese, W.L. Wakkinen, M. D. Robertson, and R. A. Fischer. 1994. Sage grouse ecology. Study I: Sage grouse response to a controlled burn. Ida. Dept. Fish \& Game. Boise, Ida.

Conrad, C.E. and C.E. Poulton. 1966. Effects of wildfire on Idaho fescue and bluebunch wheatgrass. J. Range Manage. 19:138-141.

Cook, C.W., L.A. Stoddart, and L.E. Harris. 1954. The nutritive value of winter range plants in the Great Basin. Utah Agr. Exp. Sta. Bull. 372.

Council for Agricultural Science and Technology. 1974. Livestock grazing on federal lands in the 11 western states. J. Range Manage. 27:174-181

Craddock, G.W. and C.L. Forsling. 1938. The influence of climate and grazing on spring-fall sheep range in southern Idaho. U.S.D.A. Tech. Bull. 600.
Crane, K. K., M. A. Smith, and D. Reynolds. 1997. Habitat selection patterns of feral horses in southcentral Wyoming. J. Range Manage. 50:374-380.

Crawford, J.A. and R.S. Lutz. 1985. Sage Grouse population trends in Oregon, 19411983. Murrelet 66:69-74.

Crawford, J.A., M.A. Gregg, M.S. Drut, and A.K. DeLong 1992. Habitat use by female sage grouse during the breeding season in Oregon. Final Report submitted to Bur. Land Manage., Ore. St. Univ. Corvallis, Ore.

Dahl, B.F. and E.W. Tisdale. 1975. Environmental factors related to medusahead distribution. J. Range Manage. 28:463-468.

Dalke, P.D., D.B. Pyrah, D.C. Stanton, J.E. Crawford, and E.F. Schlatterer. 1963. Ecology, productivity, and management of sage grouse in Idaho. J. Wildl. Manage. 27:811-841.

Danvir, R.E. 2002. Sage Grouse ecology and management in a northern Utah sagebrushsteppe. Wildlife Research Report, Deseret Land and Livestock Inc. Woodroff, Ut.

Dargen L.M., R.J. Keller, H.R. Shepard, and R.N. Randall. 1942. Survey of 1941-42: food studies, parasite relations, habitat requirements, including preliminary data on sharp-tailed grouse in Moffat and Routt counties. Colo. Game and Fish Comm, Sagegrouse Survey 4. Denver, Colo.

DeLong, A.K. 1994. Relationships between vegetation structure and predation rates of artificial sage grouse nests. M.S. Thesis, Ore. St. Univ. Corvallis, Ore.

DeLong, A.K., J.A. Crawford, and D.C. DeLong, Jr. 1995. Relationships between vegetational structure and predation of artificial Sage grouse nests. J. Wildl. Manage. 59:88-92.

Drut, M.S., J.A. Crawford, and M.A. Gregg. 1994a. Brood habitat use by sage grouse in Oregon. Great Basin Natural. 54:170-176.

Drut, M.S., W.H. Pyle, and J.A . Crawford. 1994b. Technical note: Diets and food selection of sage grouse chicks in Oregon. J. Range Manage. 47:90-93.

Dunn, P.O. and C.E. Braun. 1985. Natal dispersal and lek fidelity of sage grouse. Auk 102:621-627.

Dunn, P.O. and C.E. Braun. 1986. Late summer-spring movements of juvenile sage grouse. Wilson Bull. 98:83-92.

Eckert, R.E., Jr. and J.S. Spencer. 1986. Vegetation response on allotments grazed under rest-rotation management. J. Range Manage. 39:166-174.

Eckert, R.E., Jr, and J.S. Spencer, 1987. Growth and reproduction of grasses heavily grazed under rest-rotation management. J. Range Manage. 40:156-159.

Edelmann, F.B., M.J. Ulliman, M.J. Wisdom, K.P. Reese, and J.W. Connelly. 1998. Assessing habitat quality using population fitness parameters: a remote sensing/GIS-Based habitat-explicit population model for sage grouse (Centrocercus urophasianus). Ida. For., Wildl. \& Range Exp. Sta. and Univ. Ida. Contribution 846. Moscow, Ida. 
Elmore, W. and B. Kauffman. 1994. Riparian and Watershed systems: Degradation and Restoration, p. 212-231. In: M. Vavra, W.A. Laycock, and R.D. Pieper (eds.) Ecological Implications of Livestock Herbivory in the West. Society for Range Manage. Denver, Colo.

Emmons, S.R. and C.E. Braun. 1984. Lek attendance of male sage grouse. J. Wildl. Manage. 48:1023-1028.

Eng, R.L., E.J. Pitcher, S.J. Scott, and R.J. Greene. 1979. Minimizing the effects of surface coal mining on a sage grouse population by a directed shift of breeding activities, $\mathrm{p}$. 464-468. In: G.A. Swanson (tech-co-ord) The mitigation symposium. U.S.D.A. For. Serv., Gen Tech. Rept. RM-65.

Evans, C. 1986. The relationship of cattle grazing to sage grouse use of meadow habitat on the Sheldon National Wildlife Refuge. M.S. Thesis, Univ. Nev., Reno, Nev.

Fischer, R.A. 1994. The effects of prescribed fire on the ecology of migratory sage grouse in southeastern Idaho. M.S. Thesis Univ. Ida. Moscow, Ida.

Fischer, R.A., K.P. Reese, and J.W. Connelly. 1996. An investigation on fire effects within xeric sage grouse brood habitat. J. Range Manage. 49:194-198.

Fischer, R.A., W.L. Wakkinen, K.P. Reese, and J.W. Connelly. 1993. Nesting-area fidelity of sage grouse in southeastern Idaho. Condor 95:1038-1041.

Frost, W.E., E.L. Smith, and P.R. Ogden. 1994. Utilization guidelines. Rangelands 16:256-259.

Fulgham, K.O., M.A. Smith, and J.C. Malechek. 1982. A compatible grazing relationship can exist between domestic sheep and mule deer, p. 458-478. In: J.M. Peek and P.D. Dalke (eds.) Proc. of the WildlifeLivestock Relationships Symp. Idaho For., Wildl. and Range Exp. Sta., Univ. Idaho, Moscow, Ida.

Gates, R.J. 1985. Observations of the formation of a sage grouse lek. Wilson Bull. 97:219-221.

Gibbens, R.P. and H.G. Fisser. 1975. Influence of grazing management systems on vegetation in the Red Desert region of Wyoming. Univ. of Wyo. Agr. Exp. Sta. Sci. Monogr. 29.

Gibson, R.M. and J.W. Bradbury. 1986. Male and female mating strategies on sage grouse leks, p. 379-398. In: D. I. Rubenstein and R. W. Wrangham (eds.) Ecological aspects of social evolution: birds and mammals. Princeton Univ. Press, Princeton, N.J..

Gill, R.B. 1966. Weather and sage grouse productivity. Colo. Game, Fish and Parks Dep., Outdoor Info. Leaflet 37. Denver, Colo.

Glidewell, B.C., J.C. Mosley, and J.W. Walker. 2001. Sheep and cattle response when grazed together on sagebrush-grass rangeland. Proc. West. Sec. Amer. Soc. Anim. Sci. 52:156-159.

Gregg, M.A. 1992. Habitat use and selection of nesting habitat by sage grouse in Oregon. M.S. Thesis, Ore. St. Univ. Corvallis, Ore.

Gregg, M.A., J.A. Crawford, and M.S. Drut. 1993. Summer habitat use and selection by female sage grouse (Centrocercus urophasianus) in Oregon. Great Basin Nat. 53:293-298.

Gregg, M.A., J.A. Crawford, M.S. Drut, and A.K. DeLong. 1994. Vegetative cover and predation of sage grouse nests in Oregon. $\mathbf{J}$. Wildl. Manage. 58:162-166.

Gruell, G.E. 1999. Historical and modern roles of fire in pinyon-juniper, p. 24-28. In: S. B. Monsen and R. Stevens (eds.) Proc. Ecology and management of pinyon-juniper communities within the interior West.; Sept. 15-18, 1997, Provo, Ut. U.S.D.A. For. Serv. RMRSP-9.

Halstvedt, M.B. 1994. Big sagebrush (Artemisia tridentata) management with reduced rates of tebuthiuron, p. 10-13. In: Big Sagebrush (Artemisia tridentata) Management With Spike 20P Herbicide (tebuthiuron). DowElanco, Indianapolis, Ind.

Halstvedt, M.B., V.F. Carrithers, T.D. Whitson, and G. Baxter. 1996. Thinning big sagebrush canopy cover using low rates of Spike 20P herbicide. Down To Earth $51: 1-6$.

Hamerstrom, F. N., Jr., O. E. Mattson, and F. Hamerstrom. 1957. A guide to prairie chicken management. Wis. Cons. Dept. Tech. Wildl. Bull. No. 15 .

Hanf, J.M., P.A. Schmidt, and E.B. Groshend. 1994. Sage grouse in the high desert of Central Oregon: results of a study, 1988-1993. U.S.D.I.-Bur. Land Manage., Series P-SG-01, Prineville, Ore.

Harniss, R.O. and R.B. Murray. 1973. Thirty years of vegetal change following burning of sagebrush-grass range. J. Range Manage. 26:322-325.

Harrison, B.J. and A.P. Thatcher. 1970. Winter sheep grazing and forage preference in southwestern Wyoming. J. Range Manage. 23:109-111.

Hemstrom, M.A., M.J. Wisdom, W.J. Hann, M.M. Rowland, B. C. Wales, and R.A. Gravenmier. 2002. Sagebrush-steppe vegetation dynamics and restoration potential in the Interior Columbia Basin, U.S.A. Cons. Biol. 16:1243-1255.

Holechek, J.L., H. Gomez, F. Molinar, and D. Galt. 1999. Grazing studies: What we've learned. Rangelands 21: 12-16.

Holechek, J.L., R. Valdez, S.D. Schemnitz, R.D. Pieper, and C.A. Davis. 1982. Manipulation of grazing to improve or maintain wildlife habitat. Wild. Soc. Bull. 10:204-210.

Houston, D.B. 1973. Wildfires in northern Yellowstone National Park. Ecol. 54:1109-1117.

Hulet, B.V., J.T. Flinders, J.S. Green, and R. B. Murray. 1986. Seasonal movements and habitat selection of sage grouse in southern Idaho, p. 168-175. In: E.D. McArthur, and G.L. Welch (compilers) Proc. a Symposium on the biology of Artemisia and Crysothamnus. U.S.D.A. For. Serv., Gen. Tech. Rept. INT-200.

Hupp, J.W. and C.E. Braun. 1989. Topographic distribution of sage grouse foraging in winter. J. Wildl. Manage. $53 \cdot 823-829$.
Ihli, M., P. Sherbenou, and C.W. Welch. 1973. Wintering sage grouse in the Upper Big Lost River. Idaho Acad. Sci. 1973:73-80.

Jenni, D.A. and J.E. Hartzler. 1978. Attendance at a sage grouse lek: implications for spring censuses. J. Wildl. Manage. 42:46-52.

Johnson, J.R. and G.F. Payne. 1968. Sagebrush reinvasion as affected by some environmental influences. J. Range Manage. 21:209-213.

Johnson, K.H., R.A. Olson, and T.D. Whitson. 1996. Composition and diversity of plant and small mammal communities in tebuthiuron-treated big sagebrush (Artemisia tridentata). Weed Tech. 10:404-416.

June, J.W. 1963. Wyoming sage grouse population measurement. Proc. West. Assoc. State Game and Fish Comm. 43:206-211.

Kearl, G.W. and J.W. Freeburn. 1980. Economics of big sagebrush control for mitigating reductions of federal permits. M.S. Thesis, Univ. Wyo. Laramie, Wyo.

Keller, R. J., H.R. Shepherd, and R.N. Randall. 1941. Survey of 1941: North Park, Jackson County, Moffat County, including comparative data of previous season. Colo. Game and Fish Comm. Sage Grouse Surv. 3. Denver, Colo.

Klebenow, D. A. 1969. Sage grouse nesting and brood habitat in Idaho. J. Wildl. Manage. 33:649-662.

Klebenow, D. A. 1970. Sage grouse versus sagebrush control in Idaho. J. Range Manage. 23:396-400.

Klebenow, D. A. 1982. Livestock grazing interactions with sage grouse, p. 113-123. In: J.M. Peek and P.D. Dalke (eds.) Proc. of the Wildlife-Livestock Relationships Symposium. Idaho For., Wildl., and Range Exp. Sta., Univ. Idaho. Moscow, Ida.

Klebenow, D. A. 1985. Habitat management for sage-grouse in Nevada. World Pheasant Assoc. 10:34-46.

Klebenow, D. A. and R. C. Beall. 1977. Fire impacts on birds and mammals on Great Basin rangelands, p. 1-13. In: Anonymous, Proc. Joint Intermountain Rocky Mountain Fire Research Council, Casper, Wyo.

Klebenow, D. A. and G. M. Gray. 1968. The food habits of juvenile sage grouse. J. Range Manage. 21:80-83.

Kovalchick, B. L. and W. Elmore. 1992. Effects of cattle grazing systems on willowdominated plant associations in central Oregon, p. 111-119. In: W.P. Clary, E.D. McArthur, D. Bedunah, and C.L. Wambolt, (eds.) Proc. Symposium on Ecology and Management of Riparian Shrub Communities, U.S.D.A. For. Serv., Gen. Tech. Rept. INT-GTR-289.

Krysl, L. J., M. E. Hubbert, B. F. Sowell, G. E. Plumb, T. K. Jewett, M. A. Smith, and J. W. Waggoner. 1984. Horses and cattle grazing in the Wyoming Red Desert, I. Food habits and dietary overlap. J. Range Manage. 37:72-76.

Laycock, W. A. 1967. How heavy grazing and protection affect sagebrush-grass ranges. J. Range Manage. 20:206. 
Laycock, W. A. 1987. Grazing management systems and tactics in the sagebrush ecosystem, p. 40-48. In: J.A. Onsager, (ed.) Integrated Pest Management on Rangeland: State of the Art in the Sagebrush Ecosystem. U.S.D.A.-A.R.S. Bull. ARS-50.

Laycock, W.A. 1991. Stable states and thresholds of range condition on North American rangelands: A viewpoint. J. Range Mange. 44:427-433.

Laycock, W.A. and P.W. Conrad. 1967. Effect of grazing on soil compaction as measured by bulk density on a high elevation cattle range. J. Range Manage. 20:136-140.

Laycock, W.A. and P.W. Conrad. 1981. Responses of vegetation and cattle to various systems of grazing on seeded and native mountain rangelands in eastern Utah. J. Range Manage. 34:52-58.

Laycock, W.A., D. Loper, F.W. Obermiller, L. Smith, S.R. Swanson, P.J. Urness, and M. Vavra. 1996. Grazing on public lands. Council for Agr. Sci. and Tech. Task Force Rep. No. 129. Ames, Iowa.

Leonard, K.M., K.P. Reese, and J.W. Connelly. 2000. Distribution, movements and habitats of sage grouse Centrocercus urophasianus on the Upper Snake River Plain of Idaho: changes from the 1950's to the 1990's. Wildl. Biol. 6:265-270.

Lucchini, V., J. Hoglund, S. Klaus, J. Swenson, and Randi, E. 2001. Historical biogeography and a mitochondrial DNA phylogeny of grouse and ptarmigan. Molec. Phylogenetics and Evol. 20:149-162.

Lyon, L. J. and P.F. Stickney. 1976. Early vegetal succession following large Northern Rocky Mountain wildfires, p. 355-375. In: Proceedings, Tall Timbers Fire Ecology Conference No. 14 and Intermountain Fire Research Council, Fire and Land Management Symposium, Missoula, Mont., Tallahassee, Fla.

Mackie, R.J. 1970. Range ecology and relations of mule deer, elk, and cattle in the Missouri River Breaks, Montana. Wildl. Monogr. 20:1-79.

Martin, N.S. 1970. Sagebrush control related to habitat and sage grouse occurrence. J. Wildl. Manage. 34:313-320.

Martin, N.S. 1976. Life history and habitat requirements of sage grouse in relation to sagebrush treatment. Proc. of the West. Assoc. State Game \& Fish Commissioners 56:289-294.

Martin, R.C. 1990. Sage grouse responses to wildfire in spring and summer habitats. M.S. Thesis, Univ. Ida. Moscow, Ida.

McDowell, M.K.D. 2000. The effects of burning in mountain big sagebrush on key sage grouse habitat characteristics in southeastern Oregon. M.S. Thesis, Ore. St. Univ. Corvallis, Ore.

Merritt, S., C. Prosser, K. Sedivec, and D. Bangsund. 2001. Multi-species grazing and leafy spurge. U.S.D.A.-ARS Team Leafy Spurge, Sidney, Mont.

Miller, R.F. and L.L. Eddleman. 2001. Spatial and temporal changes of sage grouse habitat in the sagebrush biome. Ore. Agr. Exp. Sta. Bull. 151. Corvallis, Ore.
Miller, R.F. and J.A. Rose. 1999. Fire history and western juniper encroachment in sagebrush steppe. J. Range Manage. 52:550-559.

Miller, R.F. and R.J. Tausch. 2001. The role of fire in juniper and pinyon woodlands: a descriptive analysis, p. 15-30. In: K.E.M. Galley and T.P. Wilson (eds.) Proc. Invasive Species Workshop: the Role of Fire in the Control and Spread of Invasive Species. Misc. Pub. No. 11, Tall Timbers Res. Sta. Tallahassee, Fla.

Miller, R.F., T. Svejcar, and J.A. Rose. 2000. Western juniper succession in shrub steppe: Impacts on community composition and structure. J. Range Manage. 53:574-585.

Miller, R.F., T.J. Svejcar, and N.E. West. 1994. Implications of livestock grazing in the Intermountain sagebrush region: plant composition, p. 101-146. In: M. Vavra, W.A. Laycock, and R.D. Pieper (eds.) Ecological Implications of Livestock Herbivory in the West. Soc. for Range Manage. Denver, Colo. Miller, R.F., J. Bates, K. Davis, and L. Ziegenhagen. 2003. Sagebrush cover: community level $=$ sage grouse requirements? Proc. Society for Range Management Annual Meeting Casper, Wyo.

Mosley, J. C. 1996. Prescribed sheep grazing to suppress cheatgrass: A review. Sheep and Goat Res. J. 12:74-81.

Mosley, J.C., S.C. Bunting, and M.E. Manoukian. 1999. Cheatgrass, p. 175-188. In: R.L. Sheley and J.K. Petroff (eds.) Biology and Management of Noxious Rangeland Weeds. Ore. State Univ. Press, Corvallis.

Mosley, J.C., P.S. Cook, A.J. Griffis, and J. O'Laughlin. 1997. Guidelines for managing cattle grazing in riparian areas to protect water quality: Review of research and best management practices policy. Univ. Idaho For., Wildl. and Range Policy Analysis Group Rept. 15.

Mueggler, W.F. 1950. Effects of spring and fall grazing by sheep on vegetation of the upper Snake River plains. J. Range Manage. 3:308-315.

Muggler, W.F. and W.L. Stewart. 1980. Grassland and shrubland habitat types of western Montana. USDA For. Ser Gen. Tech Rep. INT-66.

Myers, L.H. 1989. Grazing and riparian management in southwestern Montana, p. 117-120. In: R.E. Gresswell, B.A. Barton, and J.L. Kershner (eds.) Practical Approaches to Riparian Resource Management-An Educational Workshop, U.S.D.I.-B.L.M., BLM-MT-PT-89-0014351.

Neel, L.A. 1980. Sage grouse response to grazing management in Nevada. M.S. Thesis, Univ. Nevada. Reno, Nev.

Nelson, O.C. 1955. A field study of the sage grouse in southeastern Oregon with special reference to reproduction and survival. M.S. Thesis. Ore. St. Univ. Corvallis, Ore.

Nelle, P.J., K.P. Reese, and J.W. Connelly. 2000. Long-term effects of fire on sage grouse habitat. J. Range Manage. 53:586-591.
Ngugi, K.R., J. Powell, F.C. Hinds, and R.A. Olson. 1992. Range animal diet composition in southcentral Wyoming. J. Range Manage. 45:542-545.

Oakleaf, R.J. 1971. Relationship of sage grouse to upland meadows in Nevada. M.S. Thesis, Univ. Nevada. Reno, Nev.

Olsen, F.W. and R.M. Hansen. 1977. Food relations of wild free-roaming horses to livestock and big game, Red Desert, Wyoming. J. Range Manage. 30:17-20.

Olson, B.E. and R.T. Wallander. 2001. Sheep grazing spotted knapweed and Idaho fescue. J. Range Manage. 54:25-30.

Olson, R.A. and T.D. Whitson. 1996. Improving wildlife habitat quality on sagebrush rangelands with Spike 20P herbicide. p. 7-13, In: Down To Earth. DowElanco, Indianapolis, Ind.

Olson, R.A. and T.D. Whitson. 2002. Restoring structure in late-successional sagebrush communities by thinning with tebuthiuron. Rest. Ecol. 10:146-155.

Olson, R.A., J. Hansen, and T.D. Whitson. 1996. Enhancing rangeland forage production and biodiversity with tebuthiuron, $p$. 55-59. In: K.E. Evans (ed.) Sharing Common Ground On Western Rangelands: Proc. of A Livestock/Big Game Symposium. February 26-28, 1996, Sparks, Nev. U.S.D.A. For. Serv., Gen. Tech Rept. INTGTR-343.

Olson, R.A., J. Hansen, T.D. Whitson, and K. Johnson. 1994. Tebuthiuron to enhance rangeland diversity. Rangelands 16:197-201.

Orpet, J.E. and H.G. Fisser. 1979. Long-term effects of 2,4-D applications on big sagebrush. Proc. Soc. for Range Manage. p. 29.

Patterson, R.L. 1952. The sage grouse in Wyoming. Sage Books, Inc., Denver, Colo.

Payne, G.F. 1973. The effect of 2,4-D on sagebrush and associated vegetation on the Beaverhead National Forest, Montana. Final Report. U.S.D.A., For. Ser. Final Rept., Mont. Agr. Exp. Sta.

Pearson, L.C. 1964. Effect of harvest date on recovery of range grasses and shrubs. Agron. J. 56:80-82.

Pechanec, J.F. and G. Stewart. 1949. Grazing spring-fall sheep ranges of southern Idaho. U.S.D.A. Circ. 808.

Pechanec, J.F., G. Stewart, and J.P. Balisdell. 1954. Sagebrush burning - good and bad. U.S.D.A. Farmer's Bull. 1948.

Pellant, M. 1994. History and applications of the Intermountain greenstripping program, $\mathrm{p}$. 63-68. In: S.B. Monsen and S.G. Kitchen (eds.) Proc. Ecology and Management of Annual Rangelands, U.S.D.A. For. Serv., Gen. Tech. Rept. INT-313.

Pellant, M., J. Kaltenecker, and S. Jirik. 1999. Use of OUST, herbicide to control cheatgrass in the Northern Great Basin, p. 322-326. In: S.B. Monsen and R. Stevens (compilers) Proc. Ecology and Management of Pinyon-Juniper Communities Within the Interior West. U.S.D.A. For. Serv., Gen. Tech. Rept. RMRS-P-9.

Peters, E.F. and S.C. Bunting. 1994. Fire conditions pre- and post- occurrence of annual grasses on the Snake River Plain, p. 31-36. 
In: S.B. Monsen and S.G. Kitchen (eds.) Proc. Ecology and Management of Annual Rangelands. U.S.D.A. For. Serv., Gen. Tech. Rept. INT-313.

Petersen, B.E. 1980. Breeding and nesting ecology of female sage grouse in North Park, Colorado. M.S. Thesis, Colo. St. Univ. Fort Collins, Colo.

Peterson, J.G. 1970. The food habits and summer distribution of juvenile sage grouse in central Montana. J. Wildl. Manage. 34:147-155.

Potts, G.R. 1986. The partridge. Collins, London, England.

Pyle, W.H. 1993. Response of brood-rearing habitat of sage grouse to prescribed burning in Oregon. M.S. Thesis, Ore. St. Univ. Corvallis, Ore.

Pyle, W.H. and J.A. Crawford. 1996. Availability of foods of sage grouse chicks following prescribed burning in sagebrushbitterbrush. J. Range Manage. 49:320-324.

Pyrah, D.B. 1971. Sage grouse habitat research in central Montana. Proc. West. Assoc. State Game and Fish Comm. 51:293-300.

Rasmussen, D.I. and L.A. Griner. 1938. Life history and management studies of the sage grouse in Utah, with special reference to nesting and feeding habits. Trans. North Amer. Wildl. Conf. 3:852-864.

Ratliff, R.D. and J.N. Reppert. 1974. Vigor of Idaho fescue grazed under rest-rotation and continuous grazing. J. Range Manage. 27:447-449.

Reiner, R. J. and P. J. Urness. 1982. Effect of grazing horses managed as manipulators of big

Rice, B. and M. Westoby. 1978. Vegetative responses of some Great Basin shrub communities protected against jackrabbits or domestic stock. J. Range Manage. 31:28-34.

Riegel, G. M., R.F. Miller, S.E. Smith, and C. Skinner. (in press). The history and ecology of fire in Northeastern California. In: N.G. Sugihara, M. Borchert, J. van Wagtendonk, J. Fites-Kaufmann, and K. Shaffer (eds.) Fire and Vegetation Interactions in California Ecosystems. Univ. of Calif. Press, Berekeley, Calif.

Rich, T. 1985. Sage grouse population fluctuations: evidence for a 10-year cycle. U.S. Dep. Inter., Bur. Land Manage. Tech. Bull. 85-1. Boise, Ida.

Rickard, W.H., D.W. Uresk, and J.F. Cline. 1975. Impact of cattle grazing on three perennial grasses in southcentral Washington. J. Range Manage. 28:108-112.

Riggs, R.A. and P.J. Urness. 1989. Effects of goat browsing on Gambel oak communities in northern Utah. J. Range Manage 42:354-360.

Rowland, M.M. and W.J. Wisdom. 2002. Research problem analysis for greater sagegrouse in Oregon. Final report submitted to Ore. Dept. of Fish and Wildl.

Roberson, J.A. 1986. Sage grouse-sagebrush relationships: A review, p.157-167. In: E.D. McArthur, \& B.L. Welch (eds.) Proc. of a Symposium on the Biology of Artemisia and Chrysothamnus. U.S.D.A. For Serv., Gen. Tech. Rept. INT-200.
Robertson, M.D. 1991. Winter ecology of migratory sage grouse and associated effects of prescribed fire in southeastern Idaho. M.S Thesis, Univ. Ida. Moscow, Ida.

Rogers, G.E. 1964. Sage grouse investigations in Colorado. Colo. Game, Fish and Parks Dept. Tech. Pub. 16. Denver, Colo.

Sanders, K.D. 1998. Utilization standards: the quandary revisited, p. 2-8. In: Stubble height and utilization measurements: Uses and misuses. Ore. Agr. Exp. Sta. Bull. 682. Corvallis, Ore.

Sanders, K.D. and A.S. Voth. 1983. Ecological changes of grazed and ungrazed plant communities, p. 176-179. In: S. B. Monsen and N. Shaw (eds.) Managing Intermountain Rangelands - Improvement of Range and Wildlife Habitats. U.S.D.A. For. Serv., Gen. Tech. Rept. INT-157.

Savage, D.E. 1969. Relation of sage grouse to upland meadows in Nevada. Nev. Fish and Game Comm., Job Completion Rept., Proj. W-39-R, Job 12, Reno, Nev.

Schoenberg, T.J. 1982. Sage grouse movements and habitat selection in North Park, Colorado. M.S. Thesis, Colo. St. Univ. Fort Collins, Colo.

Schneegas, E.R. 1967. Sage grouse and sagebrush control. Trans. N. Amer. Wildl. Conf. 32:270-274.

Schroeder, M.A. 1997. Unusually high reproductive effort by sage grouse in a fragmented habitat in northcentral Washington. Condor 99:933-941.

Schroeder, M. A. and R. K. Baydack. 2001. Predation and the management of prairie grouse. Wildl. Soc. Bull. 29:24-32.

Schroeder, M.A., J.R. Young, and C.E. Braun. 1999. Sage grouse (Centrocercus urophasianus), p. 1-28. In: A. Poole and F. Gill (eds.) The birds of North America. The Birds of North America, Inc., Philadelphia, Penn.

Scott, J.W. 1942. Mating behavior of the sage grouse. Auk 59:477-498.

Severson, K., M. May, and W Hepworth. 1968. Food preferences, carrying capacities, and forage competition between antelope and domestic sheep in Wyoming's Red Desert. Univ. Wyo. Agr. Exp. Sta. Sci. Monogr. 10.

Sharp, L., K. Sanders, and N. Rimbey. 1994. Management decisions based on utilization: Is it really management? Rangelands 16:38-40

Shaw, N.L. 1992. Recruitment and growth of Pacific willow and sandbar willow seedlings in response to season and intensity of cattle grazing, p. 130-137. In: W.P. Clary, E.D. McArthur, D. Bedunah, and C.L. Wambolt (eds.) Proc. Symp. on Ecology and Management of Riparian Shrub Communities. U.S.D.A. For. Serv., Gen. Tech. Rept. INT-289.

Shrader-Frechette, K.S. and E.D. McCoy. 1993. Method in Ecology: Strategies for Conservation. Cambridge Univ. Press, New York.

Smith, M.A., J.C. Malechek and K.O. Fulgham. 1979. Forage selection by mule deer on winter range grazed by sheep in spring. J. Range Manage. 32:40-45.
Stewart, G. and A.C. Hull. 1949. Cheatgrass (Bromus tectorum) - an ecologic intruder in southern Idaho. Ecol. 30:58-74.

Sveum, C.M., J.A. Crawford, and W.D. Edge. 1998a. Use and selection of broodrearing habitat by sage grouse in southcentral Washington. Great Basin Nat. 58:344-351.

Sveum, C.M., W.D. Edge, and J.A. Crawford. 1998b. Nesting habitat selection by sage grouse in southcentral Washington. J. Range Manage. 51:265-269.

Swetnam, T.W., C.D. Allen, and J.L. Betancourt. 1999. Applied historical ecology: Using the past to manage the future. Ecol. Appl. 9:1189-1206.

Tate, J. Jr., M.S. Boyce, and T.R. Smith. 1979. Response of sage grouse to artificially created display ground, p. 459-463. In: G.A. Swanson (tech-co-ord) The mitigation symposium. U.S.D.A., For. Serv., Gen Tech. Rep RM-65.

Tausch, R.J. 1999. Transitions and thresholds: influences and implications for management in pinyon and Utah juniper woodlands, p.361-365. In: Monsen, S.B., R. Stevens, R.J. Tausch, R. Miller, S. Goodrich (eds.) Proceedings of the Ecology and management of pinyon-juniper communities within the interior west, Sept. 15-18, 1997. U.S.D.A. For. Serv. RMRS-P-9.

Tisdale, E.W., M. Hironaka, and M.A. Fosberg. 1965. An area of pristine vegetation in Craters of the Moon National Monument, Idaho. Ecology 46:349-352.

Turner, M. G., R.H. Gardner and R.V. O'Neill. 2001. Landscape Ecology in Theory and Practice. Springer Verlag, New York, N.Y.

Trueblood, R.W. 1954. The effect of grass reseeding in sagebrush lands on Sage Grouse Populations. M.S. Thesis, Ut. St. Agr. Coll., Logan, Ut.

Uresk, D.W. and W.H. Rickard. 1976. The abortifacient and toxic effects of big sagebrush (Artemisia tridentata) and juniper (Juniperus osteosperma) on domestic sheep. J. Range Manage. 29:278-280.

USDI-BLM. 1990. State of the public rangelands, 1990. Bur. of Land Manage., U.S. Dept. of Interior, Washington, D.C.

Vale, T.R. 1974. Sagebrush conversion projects: An element of contemporary environmental change in the western United States. Biol. Conserv. 6:274-284.

Volland, L.A. and J.D. Dell. 1981. Fire effects on Pacific Northwest forest and range vegetation. U.S.D.A. For. Serv. Region 6, Portland, Ore.

Wagner, F.H. 1978. Livestock grazing and the livestock industry, p. 121-145. In: H. Brokaw (ed.), Wildlife in America. Council on Environmental Qual., Wash. D.C.

Waichler, W.S., R.F. Miller, and P.S. Doescher. 2001. Community characteristics of old-growth western juniper woodlands. J. Range Manage. 54:518-527.

Wakkinen, W.L. 1990. Nest site characteristics and spring-summer movements of migratory sage grouse in southeastern Idaho. M.S Thesis, Univ. Ida. Moscow, Ida. 
Wakkinen, W.L., K.P. Reese, and J.W. Connelly. 1992. Sage grouse nest locations in relation to leks. J. Wildl. Manage. 56:381-383.

Wallestad, R.O. 1971. Summer movements and habitat use by sage grouse broods in central Montana. J. Wildl. Manage. 35:129-136.

Wallestad, R.O. 1975. Life history and habitat requirements of sage grouse in central Montana. Montana Dept. Fish, Game, and Parks. Helena, Mont.

Wallestad, R.O. and D.B. Pyrah. 1974. Movement and nesting of sage grouse hens in central Montana. J. Wildl. Manage. 38:630-633.

Wallestad, R.O., J.G. Peterson, and R.L. Eng. 1975. Foods of adult sage grouse in central Montana. J. Wildl. Manage. 39:628-630.

Waltenberger, D.W., W.S. Belles, and G.A. Lee. 1979. The control of big sagebrush on central Idaho rangeland. Proc. West. Soc. Weed Sci. p. 77.

Wambolt, C.L. and G.F. Payne. 1986. An 18year comparison of control methods for Wyoming big sagebrush in southwestern Montana. J. Range Manage. 39:314-319.

Wambolt, C.L., K.S. Walhof, and M.R. Frisina. 2001. Recovery of big sagebrush communities after burning in south-western Montana. J. Environ. Manage. 61:243-252.

Washington-Allen, R.A. 2003. Retrospective ecological risk assessment of rangeland health using multi-temporal satellite imagery. PhD Diss., Utah State Univ., Logan, Ut.

Watts, M.J. and C.L. Wambolt. 1996. Longterm recovery of Wyoming big sagebrush after four treatments. J. Environ. Manage. 46:95-105.

West, N.E. 1983a. Great Basin-Colorado Plateau sagebrush semi-desert, p. 331-349. In: N.E. West (ed.) Temperate Deserts and Semideserts. Vol. 5. Ecosystems of the World, Elsevier, Amsterdam.

West, N.E. 1983b. Western Intermountain sagebrush steppe, p. 351-374. In: N.E. West (ed.) Temperate Deserts and Semideserts. Vol. 5. Ecosystems of the World, Elsevier, Amsterdam.

West, N.E. 1989. Vegetation types of Utah, p. 18-56. In: K.L. Johnson, (ed.) Rangeland resources of Utah. Coop Ext. Serv. Pub., Ut. St. Univ., Logan.

West, N.E. 1999a. Juniper-pinon savannas and woodlands of western North America, p. 284-301. In: R.C. Anderson, J.S. Fralish and J.M. Baskin (eds.) Savannas, Barrens, and Rock outcrop Plant Communities of North America. Cambridge Univ. Press, New York.

West, N.E. 1999b. Managing for biodiversity of rangelands, p. 101-126. In: W.W. Collins and C.O. Qualset (eds.) Biodiversity in Agrosystems. CRC Press, Boca Raton, Fla.

West, N.E. 2000. Synecology and disturbance regimes of sagebrush steppe ecosystems, p.15-26. In: Entwistle, P.G., A.M. Debolt, J.H. Kaltenecker and K. Steenhof (compilers) Proc. Sagebrush Steppe Ecosystems Symposium. Bureau of Land Mgt. Publ. No. BLM/ID/PT-0011001+1150.
West, N.E. and N.S. Van Pelt. 1986 Successional patterns in pinyon-juniper woodlands, p. 43-52. In: Everett, R.L. (ed.) Proc. Pinyon-juniper conference. U.S.D.A. For. Serv. Gen. Tech. Rept. INT-215.

West, N.E. and T.P. Yorks. 2002. Vegetation responses following wildfire on grazed and ungrazed sagebrush semi-desert. J. Range Manage. 55:171-181.

West, N.E. and J. A. Young. 2000. Vegetation of Intermountain valleys and lower mountain slopes, p. 255-284. In: M.A. Barbour and W.D. Billings (eds) North American Terrestrial Vegetation $2^{\text {nd }}$ ed. Cambridge Univ. Press, New York, N.Y.

Westoby, M., B. Walker, and I. Noy-Meir. 1989. Opportunistic management for rangelands not at equilibrium. J. Range Manage. 42:266-274.

Whitson, T. D. 2003. The effects of Plateau (Imazapic) on dalmatian toadflax, downy brome, Russian knapweed and perennial pepperweed. Proc. Soc. for Range Manage. Annual Meet. Casper, Wyo.

Whitson, T. D. and H. P. Alley. 1984. Tebuthiuron effects on Artemisia spp. and associated grasses. Weed Sci. 32:180-184.

Whitson, T. D., M. A. Ferrell, and H. P. Alley. 1988. Changes in rangeland canopy seven years after tebuthiuron application. Weed Tech. 2:486-489.

Whisenant, S.G. 1990. Changing fire frequencies on Idaho's River Plains: ecological and management implications, p. 4-10. In: Proc. Cheatgrass invasion shrub die-off, and other aspects of shrub biology and management. U.S.D.A. For. Serv. Tech. Rept. INT-276.

Winward, A.H. 1970. Taxonomic and ecological relationships of the big sagebrush complex in Idaho. Ph.D. Diss, Univ. of Ida., Moscow, Ida.

Winward, A.H. 1991. A renewed commitment to management of sagebrush grasslands, p. 27. In: Miller, R.F. (ed.) Management in the sagebrush steppe. Agr. Exp. Sta. Spec. Rpt. 880 . Ore. St. Univ. Corvallis, Ore.

Winward A.H. 2000. Monitoring the vegetation resources in riparian areas. USDA For. Serv. Gen. Tech. Rept. RMRS-47.

Wisdom, M. J., M. M. Rowland, B.C. Wales, M. A. Hemstrom, W. J. Hann, M. G. Raphael, R.S. Holthausen, R.A. Gravenmier, and T.D. Rich. 2002. Modeled effects of sagebrush steppe restoration on greater sage-grouse in the Interior Columbia Basin, U.S.A. Cons. Biol.16:1223-1231.

Woodward A.J. and S.D. Fuhlendorf. 2001 Influence of landscape composition and change on lesser prairie-chicken (Tympanuchus pallidicinctus) populations. Amer. Mid. Natural.145:261-274.

Wright, H.A. 1970. Response of big sagebrush and three-tip sagebrush to season of clipping. J. Range Manage. 23:20-22.

Wright, H. A. and A. W. Bailey. 1982. Fire Ecology: United States and southern Canada. John Wiley and Sons, New York, N.Y.
Wright, H.A. and J.O. Klemmedson. 1965. Effects of fire on bunchgrasses of the sagebrush-grass region in southern Idaho. Ecology 46:680-688.

Wright, H.A., L.F. Neuenschwander, and C. M. Britton. 1979. The role and use of fire in sagebrush-grass and pinyon-juniper plant communities: A state-of-the-art review. U.S.D.A. For. Serv. Gen. Tech. Rept. INT58.

Wright, J.C. and E.A. Wright. 1948. Grassland types of southcentral Montana. Ecology 29:449-460.

Wrobleski, D.W. 1999. Effects of prescribed fire on Wyoming big sagebrush communities: Implications for ecological restoration of sage grouse habitat. M.S. Thesis. Ore. St. Univ. Corvallis, Ore.

Young, J. A. and R. A. Evans. 1973. Downy brome - intruder in the plant succession of big sagebrush communities in the Great Basin. J. Range Manage. 26:410-415.

Young, J.A. and R.A. Evans. 1974. Population dynamics of green rabbitbrush in disturbed big sagebrush communities. J. Range. Manage. 27: 127-132

Young, J.A. and B.A. Sparks. 1985. Cattle in the cold desert. Ut. State Univ. Press, Logan, Utah.

Young, J.A, R.A. Evans, and J. Major. 1972. Alien plants in the great basin. J. Range Manage. 25:194-201.

Young, J.A., R.A. Evans, and P.T. Tueller. 1976. Great Basin plant communities-pristine and grazed, p. 187-215. In: R. Elston and P. Headrick (eds.) Holocene environmental change in the Great Basin. Nev. Arch. Survey, Res. Paper No. 6, Univ. of Nev., Reno. 5:194-201

Young, J.R. 1994. The influence of sexual selection on phenotypic and genetic divergence among sage grouse populations. Ph.D. Thesis, Purdue Univ. West Lafayatte, Ind.

Young, R.P. and R.F. Miller. 1985. Response of Sitanion hystrix (Nutt.) J.G. to prescribed burning. Amer. Midl. Natur. 113:182-87.

Zablan, M.A. 1993. Evaluation of sage grouse banding program in North Park, Colorado. M.S. Thesis, Colo. St. Univ. Fort Collins, Colo. 